\title{
Simple Assay, Kinetics, and Biochemical Trends for Soil Microbial Catalases
}

Michael Chabot ${ }^{1}$; Ernesto Morales ${ }^{1}$; Jacob Cummings ${ }^{1}$; Nicholas Rios ${ }^{1}$; Scott Giatpaiboon ${ }^{1}$; Rakesh Mogul ${ }^{*}$

${ }^{1}$ Cal Poly Pomona, Chemistry \& Biochemistry Department, 3801 W. Temple Ave., Pomona, CA, 91768, USA

\section{* Corresponding Author}

Rakesh Mogul

rmogul@cpp.edu

909-869-4309

Cal Poly Pomona

Chemistry \& Biochemistry Department 3801 W. Temple Ave.

Pomona, CA, 91768

USA 


\section{Abstract}

In this report, we expand upon the enzymology and biochemical ecology of soil catalases through development and application of a simple kinetic model and assay based upon volume displacement. Through this approach, we (A) directly relate apparent MichaelisMenten terms to the catalase reaction mechanism, (B) obtain upper estimates of the intrinsic rate constants for the catalase community $\left(k_{3}^{\prime}\right)$ and moles of catalase per 16S rRNA gene copy number, (C) utilize catalase specific activities (SAs) to obtain biomass estimates of soil and permafrost communities ( $L O D, \sim 10^{4}$ copy number $\mathrm{gdw}^{-1}$ ), and (D) relate kinetic trends to changes in bacterial community structure. This model represents a novel approach to the kinetic treatment of soil catalases, while simultaneously incorporating barometric adjustments to afford comparisons across field measurements. As per our model, and when compared to garden soils, biological soil crusts exhibited $\sim 2$-fold lower values for $k_{3}^{\prime}, \geq 10^{5}$-fold higher catalase moles per biomass (250-1200 zmol copy number $\left.{ }^{-1}\right)$, and $\sim 10^{4}$-fold higher SAs per biomass (74-230 fkat copy number $\left.{ }^{-1}\right)$. However, the highest SAs were obtained from permafrost and high-elevation soil communities (5900-6700 fkat copy number ${ }^{-1}$ ). In sum, these total trends suggest that microbial communities which experience higher degrees of native oxidative stress possess higher basal intracellular catalase concentrations and SAs per biomass, and that differing kinetic profiles across catalase communities are indicative of phylum and/or genus-level changes in community structure. For microbial ecology, therefore, these measures effectively serve as markers for microbial activity and abundance, and additionally provide insights into the community responses to exogenous stress. 


\section{Importance}

The efficient management of oxidative stresses arising from environmental pressures

25 are central to the homeostasis of soil microbial communities. Among the enzymes that manage

26 oxidative stress are catalases, which degrade hydrogen peroxide into oxygen gas and water. In

27 this report, we detail the development and application of a simple kinetic model and assay to

28 measure catalase reaction rates and estimate soil biomass. Our assay is based upon volume

29 displacement, and is low-cost, field-amenable, and suitable for scientists and educators from all

30 disciplines. Our results suggest that microbial communities that experience higher degrees of

31 native oxidative stress possess higher basal intracellular catalase concentrations and specific

32 activities when expressed per biomass. For microbial ecology, therefore, these measures serve

33 as biochemical markers for microbial activity and abundance, and provide insights into the

34 community responses to exogenous stress; thereby providing a novel means to study active

35 microbial communities in soils and permafrost.

36

37 Keywords

38 catalase; kinetics; assay; biomass; copy number; volume displacement; manometric;

39 permafrost; biological soil crust 

of diffusion ( $10^{7} \mathrm{M}^{-1} \mathrm{~s}^{-1}$ for soluble catalases) $(15,16)$.

Fe(heme) catalase reaction steps

$\begin{array}{ll}E\left(P-\mathrm{Fe}^{I I I}\right)+\mathrm{H}_{2} \mathrm{O}_{2} \longrightarrow \mathrm{E}\left(\mathrm{P}^{+\cdot}-\mathrm{Fe}^{\mathrm{IV}}=\mathrm{O}\right)+\mathrm{H}_{2} \mathrm{O} & \mathrm{E}\left(\mathrm{Mn}^{\prime \prime}\right)_{2}+\mathrm{H}_{2} \mathrm{O}_{2}+2 \mathrm{H}^{+} \longrightarrow \mathrm{E}\left(\mathrm{Mn}^{\prime \prime \prime}\right)_{2}+2 \mathrm{H}_{2} \mathrm{O} \\ \mathrm{E}\left(\mathrm{P}^{+\cdot}-\mathrm{Fe}^{\mathrm{IV}}=\mathrm{O}\right)+\mathrm{H}_{2} \mathrm{O}_{2} \longrightarrow \mathrm{E}\left(\mathrm{P}-\mathrm{Fe}^{\mathrm{III}}\right)+\mathrm{O}_{2}+\mathrm{H}_{2} \mathrm{O} & \mathrm{E}\left(\mathrm{Mn}^{\prime \prime \prime}\right)_{2}+\mathrm{H}_{2} \mathrm{O}_{2} \longrightarrow \mathrm{E}\left(\mathrm{Mn}^{\prime \prime \prime}\right)_{2}+\mathrm{O}_{2}+2 \mathrm{H}^{+}\end{array}$

56

57 58

\section{Introduction}

The efficient management of oxidative stresses arising from reactive oxygen species are central to homeostasis (1-3). For soil microbial communities, reactive oxygen species arise from exposures to ultraviolet radiation, oxidants, and desiccation, as well as aerobic respiration and photosynthesis (4-6). Among the array of intracellular enzymes that manage oxidative stress are the catalase enzymes, which degrade hydrogen peroxide $\left(\mathrm{H}_{2} \mathrm{O}_{2}\right)$ into oxygen gas and water (7-9). The activities of catalase enzymes are linked with all taxonomic domains, with catalase genes additionally being present in facultative and obligate anaerobic microorganisms (10-12). containing either iron-heme (Fe(heme)) or binuclear manganese $\left(\mathrm{Mn}_{2}\right)$ metal cofactors (EC 1.11.1.6), and bifunctional catalase-peroxidases containing Fe(heme) cofactors (EC 1.11.1.21). As diagramed below, each enzyme catalyzes the disproportionation of $\mathrm{H}_{2} \mathrm{O}_{2}$ in two broad reaction steps, which commences with efficient capture of $\mathrm{H}_{2} \mathrm{O}_{2}$ to yield oxidized metal cofactors $(13,14)$, and concludes with liberation of oxygen with reaction rates nearing the limits Catalases are organized into three major classes comprising monofunctional enzymes 
59 of water (17-19). For the $\mathrm{Mn}$ catalases (when beginning in the $\left(\mathrm{Mn}^{\prime \prime}\right)_{2}$ state), capture of $\mathrm{H}_{2} \mathrm{O}_{2}$

60 yields an oxidized manganese complex $\left(\left(\mathrm{Mn}^{\mathrm{III}}\right)_{2}\right)$, and irreversible liberation of two waters (11,

61 12, 20). Productive completion for both mechanisms concludes with acquisition of a second

$62 \mathrm{H}_{2} \mathrm{O}_{2}$, reduction of the metal centers, and liberation of $\mathrm{O}_{2}$ (and an additional water molecule for

63 the Fe(heme) catalases). Potential non-productive catalytic steps include formation of a

64 potential hydroxyferryl species (Compound II), which ultimately reverts back to the active

65 enzyme (18).

66

67

For microbial ecology, measures of these reactions can serve as biochemical markers for

68 intracellular biological activity, and provide insights into the community responses to

69

70

71

72 77 including waste disposal.

78

(1)

exogenous stress. Among the more commonly used measures for catalase reactions include potassium permanganate $\left(\mathrm{KMnO}_{4}\right)$ titrations $(21,22)$ and enzyme-linked colorimetric assays (23-25). Through straightforward, but relatively lengthy procedures, these methods provide single-time point rates, which are then converted to specific activities using soil mass. For $\mathrm{KMnO}_{4}$ titrations, however, the resulting specific activities are not necessarily amenable to units of enzyme activity (e.g., Units or katals), as side reactions with soil organics prevent direct stoichiometric relationships. Moreover, titrations with $\mathrm{KMnO}_{4}$ introduce several chemical safety issues including proper storage of solutions and chemical waste during field campaigns,

Alternatively, catalase rates can be measured via manometric and electrochemical approaches, which are amenable to kinetic measures of product formation $\left(\mathrm{O}_{2}\right)$ - or multiple 
81

82

83

84

85

86

87

88

89

90

91

92

93

94

95

96

97

98

99

100

\section{Materials \& Methods}

102 limited $(31,32)$.

\section{Materials}

measures of reaction progress over time. Manometric approaches are not well represented in

the current literature, with most (if not all) reported analytical assemblies being ill-suited for

field work or field campaigns (26-28). In contrast, electrochemical and gasometric measures for purified catalases, biological extracts, and finely sieved plant-based powders are fairly well described (29-31); however, reports detailing the analyses of soil-based samples are rather

catalases through development and application of a simple kinetic model and assay based upon volume displacement. This model represents a novel approach to the kinetic treatment of soil catalases, and explicitly correlates to the enzyme reaction mechanism for each type of catalase.

Moreover, our kinetic assay is low-cost, rapid, field-amenable, applicable to a variety of environmental catalases, and suitable for scientists and educators from all disciplines. In addition, by incorporating biomass and barometric terms, our model affords upper estimates of the intrinsic rate constants and moles of catalase per soil mass and biomass, while allowing for the comparison of measurements obtained across geographies. In summary, our results suggest that microbial communities from biological soil crusts, high elevation soils, and permafrost experience substantial degrees of native oxidative stresses, and accordingly exhibit high catalase activities and abundances per 16S rRNA gene copy number. 
Hydrogen peroxide was purchased as $30 \% \mathrm{w} / \mathrm{w}$ non-stabilized solutions (Sigma-Aldrich,

104

105

106

107

108

109

110

111

112

113

114

115

116

117

118

119

120

121

122

123

124

The volume displacement (VD) apparatus (Diagram 1 \& Figures S1A-C) was assembled using common laboratory supplies; no major purchases were required for assembly or reliable long-term operation of the apparatus. Materials included two $50 \mathrm{~mL}$ conical tubes, a tube rack, $<3 \mathrm{ft}$ of Tygon tubing (1/8 in, 1/4 in, 1/16 in), 1 one-hole rubber stopper ( $1.4 \times 1.1 \mathrm{in}), 1$ twohole rubber stopper (1.4 x $1.1 \mathrm{in}$ ), parafilm (optional), a $15 \mathrm{~mL}$ graduated cylinder (or a 15 or 50 $\mathrm{mL}$ conical tube), a mass balance (minimum accuracy of $0.01 \mathrm{~g}$ ), a stir plate, $3 \mathrm{~mm}$ magnetic stir

bar, and a stopwatch.

St. Louis, MO) and 3\% w/w stabilized solutions (CVS Pharmacy). Non-stabilized hydrogen peroxide, which did not contain chemical stabilizers, was immediately stored as aliquots at $20^{\circ} \mathrm{C}$. Additional reagents included bovine liver catalase (Sigma-Aldrich), HEPES (4-(2hydroxyethyl)-1-piperazineethanesulfonic acid) (VWR, Radnor, PA), NaCl (VWR), phosphatebuffered saline (PBS) tablets (VWR), and 10x PBS solution (100 mM potassium phosphate, 100

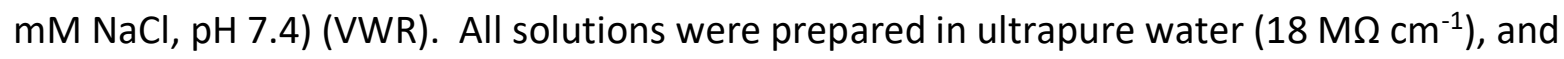
sterile filtered (0.22 $\mu \mathrm{m}$ syringe filters) or autoclaved. 


\section{Soil Samples}

Soil samples, as summarized in Table S1, were obtained from ecoregions spanning

128 differing hemispheres, elevations, annual rainfalls, and irrigation frequencies. Samples were

129 collected in duplicate or triplicate using sterile or cleaned spatula, stored in sterile 15 or $50 \mathrm{~mL}$

130 conical tubes, and analyzed immediately using field devices, within 1-5 days in makeshift or

131 field station laboratories, or within 2 weeks in a formal laboratory.

Garden and landscaped soils from sites of differing irrigation frequencies were obtained on the campus of Cal Poly Pomona (CPP) in Pomona, CA, USA between September 2017 and January 2018. Samples collected from (or near) the BioTrek Ethnobotany Garden (251 m;

138 substantial leaf litter which were irrigated 2-3 times/week and adjacent to extensive plant coverage (CPP.BioTrek.LeafLitter), and (C) non-landscaped soils that were fully removed from

140 surrounding plant cover and subjected to no regular irrigation (CPP.BioTrek.DryPatch).

141 Additional samples from CPP included bare dry topsoils that were irrigated $\leq 1 /$ week, and 142 adjacent to Japanese Iris (CPP.EnvDes.DryPatch; 255 m, 34.057205, -117.827231) and an Oak 143 tree (CPP.Quad.DryPatch; 234 m; 34.058643, -117.823691). Averaged dry weights were 144 calculated in triplicate after heating samples at $100{ }^{\circ} \mathrm{C}$ for $48 \mathrm{~h}$ (VWR 1530 Incubator). 
Cold, dry, and high elevation soils were obtained from the Tibetan Plateau in Ladakh,

147 India (3300-5400 m) in August 2017 (33). Samples were collected between sparse and small

148 plant coverage near Tso Kar Lake (4592 and 4594 m; 33.315731, 77.955639), Taglang La (5383

149 m; 33.508517, 77.771442), and Khardung La (5359 m; 34.279661, 77.603806). Samples were

150 also collected from a regularly irrigated vegetable garden at the Silk Road Cottages in Sumur

151 (3300 m; 34.624553, 77.622154).

152

Permafrost samples were collected near Tso Kar Lake (5350 m; 33.315731, 77.955639)

154 in Ladakh, India in August 2017, and analyzed within 1 day of acquisition. Alaskan permafrost

155 samples (139 m; 64.951, -147.621) were collected in 2012 by Mackelprang et al. at the United

156 States Army Cold Regions and Research and Engineering Laboratory (CRREL) permafrost tunnel

157 in Fox, Alaska; samples were stored at $-20^{\circ} \mathrm{C}$, and analyzed in 2016 for this study.

158

Black-crusted biological soil crusts (BSCs) samples were obtained in March 2016 from

163 included the BSC topsoils (top $1 \mathrm{~cm}$ of the black crust) and BSC subsurfaces (the following $1 \mathrm{~cm}$ 164 of crust).

Alkaline evaporate samples were obtained from Soda Lake (283 m; 35.148570, -

167 116.091136) in March 2016 from the Mojave National Preserve near Baker, CA, USA (off of 
Zzyzx Rd.). Samples from a $\sim 30 \mathrm{~cm}$ depth profile were collected using a metal coring device.

However, due to the loosely associated evaporates, coring resulted in significant compression of the sample; thereby, yielding a final $\sim 10 \mathrm{~cm}$ core. Sub-samples were extracted at $1 \mathrm{~cm}$ increments, andaqueous extracts of the surface samples provided $\mathrm{pH}$ values of $\geq 11$.

\section{Kinetic Assays with Soil Samples}

Reaction rates were measured by volume displacement (VD) and electrochemical detection (EC). Devices for VD and EC were assembled as described in the Supplementary Materials. As per Diagram 1 (and Figures S1A-C), the VD apparatus comprised sequentially connected chambers respectively used for mixing, water displacement, and water collection. For VD, the mass of collected water over time was proportional to the rate of product formation.

$$
\text { included BSCs studied in laboratory settings }(n=3) \text {, BSCs }
$$

studied in the field $(n=2)$, dry high-elevation soils from

Ladakh ( $n=3)$, CPP soils ( $n=3)$, Ladakh permafrost $(n=2)$,

Alaskan permafrost studied at $22{ }^{\circ} \mathrm{C}(\mathrm{n}=9)$, and Alaskan permafrost studied at $4{ }^{\circ} \mathrm{C}(\mathrm{n}=3)$. For EC (Figure S1D), this

included BSCs studied in laboratory settings $(n=5), B S C S$

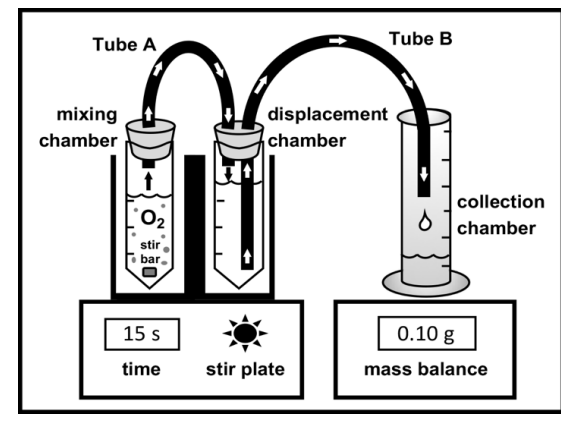

Diagram 1. Volume displacement device with sequentially connected mixing, displacement, and collection chambers.

studied in the field $(n=2)$, Alaskan permafrost studied at $22^{\circ} \mathrm{C}(\mathrm{n}=3)$, and Soda Lake samples $(n=2)$. For all studies, a new conical tube was used for each reaction. 

debris. Most samples were subsequently crushed for $30 \mathrm{~s}$ using a mortar and pestle. Prepared soils (1-10 g) were transferred to the VD and EC mixing chambers using $\sim 1.0 \mathrm{~g}$ for garden and landscaped soils, high-elevation dry soils, or BSCs, 1-2 g for Alaskan permafrost, and $10 \mathrm{~g}$ for Tso vigorously mixed using a $3 \mathrm{~mm}$ stir bar and magnetic stir plate (medium setting). All reactions were $30 \mathrm{~mL}$ in final volume, and initiated by the addition of substrate using non-stabilized or stabilized formulations of hydrogen peroxide $\left(\mathrm{H}_{2} \mathrm{O}_{2}\right)$. containing $3 \mathrm{~mL}$ 10x buffer solution (500 mM HEPES, pH 7.5) and sufficient ultrapure water to achieve a final reaction volume of $30 \mathrm{~mL}$. Enzymatic reactions were initiated by the addition of concentrations of $20-700 \mathrm{mM} \mathrm{H}_{2} \mathrm{O}_{2}$. For specific activity measurements, final $\mathrm{H}_{2} \mathrm{O}_{2}$ resuspended in $29 \mathrm{~mL}$ buffer, and reactions initiated with $1 \mathrm{~mL} 30 \% \mathrm{w} / \mathrm{w}$ non-stabilized $\mathrm{H}_{2} \mathrm{O}_{2}$. When using stabilized $\mathrm{H}_{2} \mathrm{O}_{2}$, soil samples were resuspended in $20 \mathrm{~mL}$ buffer, and reactions initiated with $10 \mathrm{~mL} 3 \% \mathrm{w} / \mathrm{w}$ stabilized $\mathrm{H}_{2} \mathrm{O}_{2}$. 
212 in the collection chamber every $15 \mathrm{~s}$ for at least $120 \mathrm{~s}$. For EC, reactions were monitored by

213 following the change in $\% \mathrm{O}_{2}$ every $2 \mathrm{~s}$ for at least $300 \mathrm{~s}$. Kinetic assays were conducted at $22{ }^{\circ} \mathrm{C}$

214 in a formal chemistry laboratory at CPP (BSCs, CPP soils, and Alaskan permafrost), at $4{ }^{\circ} \mathrm{C}$ using

215 a reach-in refrigerator at CPP (Alaskan permafrost), at $21^{\circ} \mathrm{C}$ in a makeshift laboratory in Ladakh,

216 India (Ladakh dry soils and permafrost), and at $28-32{ }^{\circ} \mathrm{C}$ in the field station laboratory at the

217 California State University (CSU) Desert Studies Center (BSCs and Soda Lake).

221 the grams of water displaced per second $\left(\mathrm{g} \mathrm{H}_{2} \mathrm{O}\right.$ displaced s$\left.{ }^{-1}\right)$. For EC experiments, regressions

222 (LabQuest 2) were performed over the linear portion of the plots (minimum of $20 \mathrm{~s}$ or 10 data

223 points), and rates expressed as the $\% \mathrm{O}_{2}$ detected per minute $\left(\% \mathrm{O}_{2} \mathrm{~min}^{-1}\right)$. As described in

224 below, all rates were converted to $\mu$ moles $\mathrm{H}_{2} \mathrm{O}_{2}$ consumed per second ( $\mu$ moles s ${ }^{-1}, \mu$ kat) and

225 expressed as specific activities. For Michaelis-Menten analyses, substrate concentrations were

226 normalized to soil mass $\left(\mathrm{mM} \mathrm{g}^{-1}\right)$, and non-linear least squares regressions (Microsoft Excel)

227 provided the apparent $\left({ }^{*}\right)$ parameters of $K_{M}^{*}$ and $V_{\text {max }}^{*}$.

Field Assays

For field assays (Figure S1C), the VD and EC devices relied on a battery-powered stir plate (MagneStir) and analytical balance (Digital Scale, China). During an expedition in the

232 Mojave National Preserve (March 2016), assays were conducted in the field on BSCs 
234 size plastic container ( 16 gal capacity), which alternatively served as a housing for the field

235 apparatus during the analyses (Figure S1E). To ensure reagent integrity, 30\% $w / w$ non-

236 stabilized $\mathrm{H}_{2} \mathrm{O}_{2}$ solutions were stored on ice packs in a foam cooler (while the $3 \% \mathrm{w} / \mathrm{w}$

237 stabilized $\mathrm{H}_{2} \mathrm{O}_{2}$ solutions were stored at ambient conditions). To minimize the impacts of

238 wind (especially during weighing of samples), an umbrella was held in position near the VD

239 and EC assemblies. At the CSU Desert Studies Center, electric-powered devices were used

240 when conducting experiments in the field station laboratory $\left(28-32^{\circ} \mathrm{C}\right)$. During a field

241 campaign in Ladakh, India (August 2017), VD assays were conducted in the city of Leh (3409

$242 \mathrm{~m})$ in the meeting/conference room at the Mogol Hostel $\left(21^{\circ} \mathrm{C}\right)$. For transport to India,

243 supplies (e.g., disassembled apparatus, pipets, and battery-operated devices) were safely

244 organized in a travel suitcase/backpack and transported as checked-in baggage during

245 international and domestic flights. Assays in Ladakh were conducted using 1x PBS (prepared

246 using PBS tablets and bottled drinking water) and stabilized $3 \% w / w \mathrm{H}_{2} \mathrm{O}_{2}$ (obtained from a

247 pharmacy in Delhi, India); all solutions were stored at ambient conditions.

\section{Unit Conversions \& Expression of Specific Activity}

Reaction rates from VD and EC experiments were converted to SI units of $\mu$ katal ( $\mu$ kat),

or the micromoles of substrate consumed per second (where $1 \mu$ kat $=60$ Units), and expressed

253 16S rRNA gene copy numbers (copy number ${ }^{-1}$ ), or grams of protein $\left(\mathrm{mg}^{-1}\right)$. For VD experiments,

254 measured reaction rates $\left(\mathrm{g} \mathrm{H}_{2} \mathrm{O}\right.$ displaced $\left.\mathrm{s}^{-1}\right)$ were firstly divided by the density of water to

255 provide the volume of water displaced per second $\left(\mathrm{mL} \mathrm{H}_{2} \mathrm{O}\right.$ displaced $\left.\mathrm{s}^{-1}\right)$. Due to the 
256

257

258

259

260

261

262

263

264

265

266

267

268

269

270

271

272

273

274

275

276

proportional displacement of water by the evolved oxygen gas, the volume of displaced water by the reaction (per second) was assumed equal to the volume of oxygen released into the gas phase (per second). The volume of oxygen released $\left(\mathrm{mL} \mathrm{O}_{2}\right.$ released s$\left.{ }^{-1}\right)$ was then converted to the moles of oxygen released $(n)$ through the ideal gas law $(P V=n R T)$ using the gas constants of $8.314 \mathrm{~L} \mathrm{kPa} \mathrm{K}^{-1} \mathrm{~mol}^{-1}$ or $0.08205 \mathrm{~L} \mathrm{~atm} \mathrm{~K}^{-1} \mathrm{~mol}^{-1}$.

To enact the conversion to moles, the partial pressure of oxygen $\left(P_{\mathrm{O}_{2}}\right)$ was obtained using Dalton's law (Equation 1), which corrected for the impacts of water vapor $\left(P_{\mathrm{H}_{2} \mathrm{O}}\right)$ on the total pressure $\left(P_{T}\right)$. In turn, the partial pressure of water $\left(P_{\mathrm{H}_{2} \mathrm{O}}\right)$ was obtained from Equation 2, where the saturation vapor pressure $\left(P_{\mathrm{H}_{2} \mathrm{O}}^{s a t}\right)$ and relative humidity $(R H)$ at the respective temperatures and sites of experimentation were obtained from online resources (e.g., Weather Underground and Google Maps), CRC handbook, or hand-held devices.

$$
P_{T}=P_{O_{2}}+P_{H_{2} O}
$$

$$
R H=\left(P_{\mathrm{H}_{2} \mathrm{O}} / P_{\mathrm{H}_{2} \mathrm{O}}^{\text {sat }}\right) x 100
$$

To account for the impacts of elevation ( $z$; meters) and temperature (T; Kelvin), the total pressure was adjusted using the barometric formula outlined in Equation 3 (34), where $P_{T}$ was assigned as the station pressure $\left(P_{z}\right)$ and calculated by adjusting the sea level pressure $\left(P_{0}\right)$, or equivalent pressure at sea level (obtained from Weather Underground). Simplification to Equation 4 was afforded by combining all constant terms in to yield $3.417 \times 10^{-2} \mathrm{~K} \mathrm{~m}^{-1}$, which included the molar mass of Earth's air (M; $28.97 \mathrm{~g} \mathrm{~mol}^{-1}$; assuming $78 \% \mathrm{~N}_{2}, 21 \% \mathrm{O}_{2}$, and $1 \% \mathrm{Ar}$ ), acceleration of gravity $\left(\mathrm{g} ; 9.80665 \mathrm{~m} \mathrm{~s}^{-2}\right)$, and gas constant $\left(\mathrm{R} ; 8314 \mathrm{~g} \mathrm{~m}^{2} \mathrm{~s}^{-2} \mathrm{~K}^{-1} \mathrm{~mol}^{-1}\right.$, or $8.314 \mathrm{~J}$ 
$277 \mathrm{~K}^{-1} \mathrm{~mol}^{-1}$, where $\mathrm{J}=\mathrm{kg} \mathrm{m}^{2} \mathrm{~s}^{-2}$. Upon conversion using the ideal gas law, the moles of oxygen

278 released per second (moles $\mathrm{O}_{2}$ released s${ }^{-1}$ ) were then converted to the micromoles of $\mathrm{H}_{2} \mathrm{O}_{2}($ or

279 substrate) consumed per second ( $\mu$ kat; or $\mu$ moles $\mathrm{H}_{2} \mathrm{O}_{2}$ consumed $\mathrm{s}^{-1}$ ) using the reaction

280 stoichiometry. All rates were expressed as specific activities ( $\mu \mathrm{kat} \mathrm{g}^{-1}, \mu \mathrm{kat} \mathrm{gdw}^{-1}$, or $\mu \mathrm{kat}$ copy

281 number-1).

100) as the 'volume of oxygen' measured $\left(\mathrm{cm}^{3}\right)$ per 'volume of the total headspace' $\left(\mathrm{cm}^{3}\right)$ per

second $\left(\mathrm{cm}^{3} \mathrm{O}_{2} \mathrm{~cm}^{-3} \mathrm{~s}^{-1}\right)$. In turn, the rate was transformed to the 'volume of oxygen' measured

headspace $(\sim 20 \mathrm{~mL})$, connective tubing $(\sim 2 \mathrm{~mL})$, and internal sensor volume $(\sim 54 \mathrm{~mL})$.

290 Conversion of volume to the 'moles of oxygen' measured per second (moles $\mathrm{O}_{2} \mathrm{~s}^{-1}$ ) was thus

291 afforded using the ideal gas law and $P_{\mathrm{O}_{2}}$, as described. All EC rates were converted to

292 micromoles of $\mathrm{H}_{2} \mathrm{O}_{2}$ consumed, and expressed as specific activities ( $\mu$ kat $\mathrm{g}^{-1}$ or $\mu k a t \mathrm{mg}^{-1}$ ).

\section{Kinetic Assays with Soluble Enzymes}

Specific activities were measured for bovine liver catalase and clarified extracts of 
HEPES (pH 7.5). Extracts of $A$. radioresistens 50v1 were prepared and characterized as described (9). Reactions with soluble enzymes were conducted in $50 \mathrm{mM} \mathrm{HEPES} \mathrm{(pH} \mathrm{7.5)} \mathrm{using}$ 20 mM non-stabilized $\mathrm{H}_{2} \mathrm{O}_{2}$.

For VD and EC assays, reactions were $30 \mathrm{~mL}$ in final volume and contained $2.1 \mathrm{nM}(0.50$ $\mu \mathrm{g} / \mathrm{mL}$ ) bovine liver catalase, or $0.015 \mathrm{mg} / \mathrm{mL}$ (or $3.0 \mathrm{~mL}$ ) of the clarified extract from $A$.

radioresistens 50v1. Enzymatic reactions were initiated by addition of a final concentration of $20 \mathrm{mM} \mathrm{H}_{2} \mathrm{O}_{2}$. Reactions were monitored and rates calculated as described. All reactions rates were reproduced (bovine liver catalase, $n=6$ for VD and $n=5$ for EC; for the 50v1 extract, $n=3$ for $V D$ and $n=2$ for $E C)$.

For absorbance spectroscopy (Beckman DU-640), solutions were $1 \mathrm{~mL}$ in final volume, and contained $50 \mathrm{mM}$ HEPES ( $\mathrm{pH}$ 7.5) and $20 \mathrm{mM} \mathrm{H}_{2} \mathrm{O}_{2}$. Enzyme reactions were initiated by the addition of $2.1 \mathrm{nM}(0.50 \mu \mathrm{g} / \mathrm{mL}$ ) bovine liver catalase, or $0.015 \mathrm{mg} / \mathrm{mL}$ (or $100 \mu \mathrm{L}$ ) of the $50 \mathrm{v} 1$ extract (final concentrations). Reaction progress was monitored by following the change in absorbance every $2 \mathrm{~s}$ at $240 \mathrm{~nm}$ (for at least $60 \mathrm{~s}$ ), where decreases in absorbance correlated to the consumption of $\mathrm{H}_{2} \mathrm{O}_{2}$ by catalase. Reaction rates were calculated using $\mathrm{R}^{2}$ values of $\geq 0.95$ over a minimum of $14 \mathrm{~s}$ (or 7 data points); however, in practice, most regressions were $\mathrm{R}^{2} \geq$ 0.99. Reaction rates $\left(\mu \mathrm{mol} \mathrm{s}{ }^{-1}\right)$ were calculated using the molar extinction coefficient for $\mathrm{H}_{2} \mathrm{O}_{2}$ $\left(43.6 \mathrm{M}^{-1} \mathrm{~cm}^{-1}\right)$, and total reaction volume $(1 \mathrm{~mL})$. Specific activities were expressed per $\mathrm{mg}$ of protein $\left(\mu \mathrm{kat} \mathrm{mg}^{-1}\right)$, and all reaction rates were reproduced $(n=6$, bovine liver catalase; $n=3$, 50v1 extract). 


\section{Results}

\section{Volume Displacement}

The suitability of the VD apparatus for catalase enzymology was assessed by measuring the impacts of soil type, autoclaving, reaction time, substrate concentration, and repeated measurements on the rates of reaction. As exhibited in the rate plots in Figure 1A, addition of $330 \mathrm{mM}$ hydrogen peroxide $\left(1 \% \mathrm{w} / \mathrm{v} \mathrm{H}_{2} \mathrm{O}_{2}\right)$ to highly irrigated garden soils

(Alaskan.PF) resulted in the displacement of appreciable amounts of water at $\sim 8,4$, and $0.2 \mathrm{~g}$

over 120 s, respectively. Autoclaved BSCs and permafrost provided no displacement (or activity), which supported a biochemical basis for the degradation of $\mathrm{H}_{2} \mathrm{O}_{2}$. Additionally, bare topsoils with very low ATP abundances, but appreciable $16 \mathrm{~S}$ rRNA gene copy numbers ( $10^{5}$ contributions from geochemical sources (35). relative standard deviation (RSD) of $5.1 \%$ for the measurements were obtained, which indicated examples for BSCs at differing substrate concentrations. As per Figure 1C, the change in

341 catalase specific activities $\left(\mu \mathrm{kat}_{\mathrm{gdw}}{ }^{-1}\right.$ ) across $50-700 \mathrm{mM} \mathrm{H}_{2} \mathrm{O}_{2}$ for all tested soils reasonably 
sum of squares of 0.0412 for high-surface density (HD) BSCs, 0.0909 for intermediate-surface density (ID) BSCs, and 0.348 for the irrigated garden soil). In practice, the VD device (as assembled) exhibited a functional lower detection limit of $\sim 0.2 \mu \mathrm{kat}$ when using $1 \mathrm{~g}$ of soil (or 12 Units), as was readily observed during analysis of alkaline evaporates, where catalase rates at $1-3 \mathrm{~cm}$ along the compressed core were not observable by VD, but were measurable by EC to

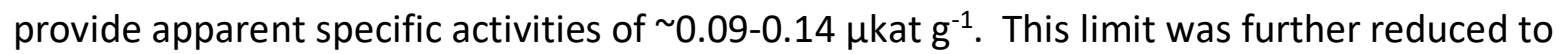
$0.06 \mu \mathrm{kat} \mathrm{g}^{-1}$ when using $10 \mathrm{~g}$ of sample, as was observed with Ladakh permafrost.

\section{Impacts of Buffer \& Substrate Formulation}

The impacts of buffer identity and substrate formulation on the catalase specific activities $\left(\mu \mathrm{kat} \mathrm{gdw}^{-1}\right.$ ) across 7 different samples were measured by VD (Figure S2). Given the potential for inhibition by $\mathrm{NaCl}$ on catalases (36), we compared the impacts of $50 \mathrm{mM} \mathrm{HEPES}$ $(\mathrm{pH} 7.5)$ and $1 \times$ PBS on the enzyme reaction rates. In addition, we measured the inhibitory impacts of the stabilizing agents found in commercially-available $\mathrm{H}_{2} \mathrm{O}_{2}$ solutions. Formulations of $\mathrm{H}_{2} \mathrm{O}_{2}$ referred to as 'stabilized $\mathrm{H}_{2} \mathrm{O}_{2}$ ' contain chemical agents that prevent (or slow) the decomposition of $\mathrm{H}_{2} \mathrm{O}_{2}$ (e.g., colloidal stannate, phosphates, sodium pyrophosphate, phosphonates, nitrate, and colloidal silicate $(37,38))$. As per Figure $\mathbf{S 2}$, the highest catalase specific activities were obtained when using HEPES and non-stabilized $\mathrm{H}_{2} \mathrm{O}_{2}$. When using nonstabilized $\mathrm{H}_{2} \mathrm{O}_{2}$, comparisons across the buffers revealed an $\sim 30-50 \%$ inhibition in PBS ( $p \leq 0.04$ ) for microbial catalases from permafrost, moderately-irrigated landscaped soils with adjacent plant coverage (CPP.EnvDes.DryPatch), and dry soils with no adjacent plant coverage (CPP.BioTrek.DryPatch). When using HEPES, comparisons across $\mathrm{H}_{2} \mathrm{O}_{2}$ formulation revealed an 
$\sim 30 \%$ inhibition when using stabilized $\mathrm{H}_{2} \mathrm{O}_{2}(p<0.02)$ for microbial catalases from $\mathrm{BSC}$

(Mojave.BSC.Field) and moderately-irrigated landscaped soils soils with adjacent plant coverage

367 (CPP.EnvDes.DryPatch).

\section{Comparison Across Techniques} spectroscopy (AS). Across these techniques, AS provided measures of substrate concentration

$373\left(\mathrm{H}_{2} \mathrm{O}_{2}\right)$ in the aqueous phase, while VD and EC provided measures of product $\left(\mathrm{O}_{2}\right)$ in the gas

375 the micromoles of $\mathrm{H}_{2} \mathrm{O}_{2}$ consumed per second per mg protein ( $\mu$ kat $\mathrm{mg}^{-1}$ ). For $\mathrm{BLC}$, SA values

376 from AS $\left(339 \pm 9 \mu\right.$ kat $\left.\mathrm{mg}^{-1}\right)$ were $\sim 5$-fold higher than those from VD and EC (at $\left.20 \mathrm{mM} \mathrm{H}_{2} \mathrm{O}_{2}\right)$,

377 which were equivalent $\left(65 \pm 12 \mu \mathrm{kat} \mathrm{mg}^{-1} ; 66 \pm 19 \mu \mathrm{kat} \mathrm{mg}^{-1}\right)$. Similarly, for the 50v1 extract, SA

378 values from AS $\left(6.3 \pm 0.7 \mu \mathrm{kat} \mathrm{mg}^{-1}\right)$ were $\sim 3$ and 6-fold higher than VD and EC, respectively (1.9

$379 \pm 0.1 \mu$ kat mg-1 $\left.; 1.0 \pm 0.3 \mu \mathrm{kat} \mathrm{mg}^{-1}\right)$. This indicated that the degradation of $\mathrm{H}_{2} \mathrm{O}_{2}$ by soluble

the gas phase and $\sim 70-85 \%$ dissolved in the aqueous buffer (and/or trapped as gas bubbles,

which were typically visible after $30-80$ s across all samples).

For BSCs, traditional measures of catalase SAs were unsuccessful. When using AS, 
387 (presumably due to the high organic content in the BSCs). Reproducible rates were only obtained when using VD or EC. Values for BSCs from VD and EC were respectively equivalent in field station and field experiments. In field station measurements, and when using nonstabilized $\mathrm{H}_{2} \mathrm{O}_{2}$, SAs of $4.0 \pm 0.3 \mu \mathrm{kat} \mathrm{gdw}^{-1}(\mathrm{n}=3)$ and $3.8 \pm 0.3 \mu \mathrm{kat} \mathrm{gdw}^{-1}(\mathrm{n}=5)$ were obtained from VD and EC, respectively. In field-based measurements, and when using stabilized $\mathrm{H}_{2} \mathrm{O}_{2}$, SAs of $4.3 \pm 1.8 \mu \mathrm{kat} \mathrm{gdw}^{-1}(\mathrm{n}=5)$ and $4.0 \pm 0.2 \mu \mathrm{kat} \mathrm{gdw}^{-1}(\mathrm{n}=2)$ were obtained from VD and EC, respectively. Together, this indicated that the moles of $\mathrm{O}_{2}$ estimated by volume displacement were equivalent to those measured by electrochemical detection (e.g., $\mathrm{O}_{2}$ Gas Sensor). For the permafrost and 50v1 extract samples, however, VD reproducibly provided $\sim 2$-fold higher values than EC, which was suggestive of the presence of alternative gas-liberating degradation pathways for $\mathrm{H}_{2} \mathrm{O}_{2}$, which were observable by VD and AS, but not EC.

\section{Kinetic Model for Soil Catalases}

Rate data were modeled to the catalase reaction sequence provided in Diagram 2,

401 which begins with the soil matrix catalases $\left(E_{\text {soil }}\right)$ in the reduced state, inclusive of the

402 Fe"(heme) and (Mn") 2 cofactors; catalysis beginning with the oxidized Mn catalases was

403 considered to be minimal (20). Therefore, in this model the combined steady state included

404 formation and breakdown of the oxidized soil microbial catalases $\left(E_{\text {soil }}^{o x}\right)$, inclusive of Compound 4051 and the $\left(\mathrm{Mn}^{\prime \prime \prime}\right)_{2}$ catalase (Equations 5 \& 6) $(13,14,39)$. 
As described by $k_{1}\left(\mathrm{M}^{-1} \mathrm{~s}^{-1}\right)$, the formation of $E_{\text {soil }}^{\text {ox }}$ encompassed several steps including equilibration of $\mathrm{H}_{2} \mathrm{O}_{2}$ into the soil suspension, capture of $\mathrm{H}_{2} \mathrm{O}_{2}$ by the catalases $\left(E_{\text {soil }}\right)$ in the biological matrix, and irreversible formation of the oxidized enzyme. As per $k_{2}\left(\mathrm{~s}^{-1}\right)$, nonproductive breakdown of $E_{\text {soil }}^{o x}$ included degradation back to native enzyme via Compound II and/or reduction of the $\mathrm{Mn}$ cofactor. Productive breakdown of $E_{\text {soil }}^{\text {ox }}$, as per $k_{3}^{\prime}\left(\mathrm{s}^{-1}\right)$, was treated as a pseudo $1^{\text {st }}$ order reaction (where $\left[\mathrm{H}_{2} \mathrm{O}_{2}\right] \gg>\left[E_{\text {soil }}^{\text {ox }}\right]$ ) that encompassed rapid

413 acquisition of the second substrate $\left(\mathrm{H}_{2} \mathrm{O}_{2}\right)$, formation of products $\left(\mathrm{O}_{2}\right.$ and $\left.\mathrm{H}_{2} \mathrm{O}\right)$, and release of detection by VD and EC) was described by Henry's Law $\left(K_{H}=P_{O_{2}} /\left[O_{2(a q)}\right]\right)$.

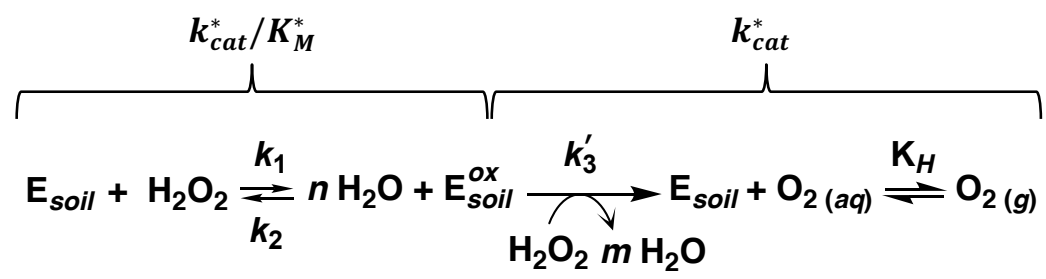

Diagram 2. Simplified reaction sequence for soil catalases $\left(E_{\text {soil }}\right)$, where $n=1$ and $m=1$ for $\mathrm{Fe}$ (heme)-catalases, and $n=2$ and $m=0$ for $\mathrm{Mn}$ catalases.

418 included enzymatic formation $\left(k_{3}^{\prime}\right)$ and liberation of $\mathrm{O}_{2}$ into the gas phase. As per Henry's Law,

419 the moles of gaseous $\mathrm{O}_{2}$ were obtained from the oxygen partial pressure and ideal gas law $420\left(K_{H}=n O_{2(g)}(R T / V) /\left[O_{2(a q)}\right]\right)$. In turn, a modified Michaelis-Menten equation (Equation 8) 421 was derived by inclusion of steady state and mass balance terms (Equation 6), where $K_{M}^{*}=$ $422\left(k_{2}+k_{3}^{\prime}\right) / k_{1}$. To incorporate soil mass terms, a soil biomass ratio $\left(R_{s}\right)$ was introduced into the 423 kinetic treatment, where $R_{s}$ related the total moles of catalase in the soil microbial community 424 to the equivalent and total grams of dried bioactive soil $\left.\left(R_{S}=\left(E_{\text {soil }}\right)_{T}^{\text {moles }} /\left(E_{\text {soil }}\right)_{T}^{g}\right)\right)$. Thus, as 
425

426

427

428

429

430

431

432

433

434

435

436

437

438

439

440

441

442

443

per Equation 6, the total enzyme concentration, $\left[E_{\text {soil }}\right]_{T}$, was expressed as $R_{S}\left(E_{\text {soil }}\right)_{T}^{g} / V$. For this expression, multiplication of $R_{S}$ by $\left(E_{\text {soil }}\right)_{T}^{g}$ yielded $\left(E_{\text {soil }}\right)_{T}^{\text {moles }}$, which in turn provided $\left[E_{\text {soil }}\right]_{T}$ after division by the reaction volume $(V)$. As per Equation $\mathbf{8}$, the assembled rate equation was thus simplified by combining $k_{3}^{\prime}\left(\mathrm{s}^{-1}\right), K_{H} V / R T(\mathrm{~L})$, and $R_{S} / V\left(\mathrm{M} \mathrm{gdw}^{-1}\right)$ to yield the parameter of $k_{\text {cat }}^{\prime}$ (in units of moles $\mathrm{s}^{-1} \mathrm{gdw}^{-1}$ ).

$$
k_{1}\left[E_{\text {soil }}\right]\left[\mathrm{H}_{2} \mathrm{O}_{2}\right]=k_{2}\left[E_{\text {soil }}^{\prime}\right]+k_{3}^{\prime}\left[E_{\text {soil }}^{\prime}\right]
$$

$$
-2 \frac{d \mathrm{H}_{2} \mathrm{O}_{2} \mathrm{~mol}}{d t}=\frac{d O_{2(\mathrm{~g})} \mathrm{mol}}{d t}=\left(\frac{K_{H} V}{R T}\right) \frac{d\left[O_{2(a q)}\right]}{d t}=\left(\frac{K_{H} V}{R T}\right) k_{3}^{\prime}\left[E_{\text {soil }}^{\prime}\right]
$$

$$
\frac{d O_{2(g)} \mathrm{mol}}{d t}=\frac{\left(\frac{K_{H}}{R T}\right) k_{3}^{\prime} R_{S}\left(E_{\text {soil }}\right)_{T}^{g}\left[H_{2} O_{2}\right]}{\left(\left(k_{2}+k_{3}^{\prime}\right) / k_{1}\right)+\left[H_{2} O_{2}\right]}=\frac{k_{c a t}^{*}\left(E_{\text {soil }}\right)_{T}^{g}\left[H_{2} O_{2}\right]}{K_{M}^{*}+\left[H_{2} O_{2}\right]}=\frac{V_{\text {max }}^{*}\left[H_{2} O_{2}\right]}{K_{M}^{*}+\left[H_{2} O_{2}\right]}
$$

Accordingly, regression analyses provided the apparent $\left(^{*}\right)$ terms of $V_{\max }^{*}$ ( $\mu$ mole s${ }^{-1}$;

$\mu$ kat) and $K_{M}^{*}\left(\mathrm{mM} \mathrm{g}^{-1}\right)$, which represented the maximal rate of $\mathrm{H}_{2} \mathrm{O}_{2}$ degradation by the soil catalase community $\left(V_{\max }^{*}\right)$, and the $\left[\mathrm{H}_{2} \mathrm{O}_{2}\right]$ required (per gram of soil) to reach $50 \%$ of the $V_{\max }^{*}$

$\left(K_{M}^{*}\right)$. For this study, the calculated term of apparent turnover number $\left(k_{\text {cat }}^{*}=V_{\text {max }}^{*} /\left(E_{\text {soil }}\right)_{T}^{g}\right)$ represented the maximal rate of $\mathrm{H}_{2} \mathrm{O}_{2}$ degradation per gram of dried soil ( $\mu \mathrm{kat} \mathrm{gdw}^{-1}$ ), and the 
444 calculated term of apparent specificity constant $\left(k_{c a t}^{*} / K_{M}^{*}\right)$ was expressed in units of $\mathrm{gdw}^{-1} \mathrm{~s}^{-1}$

445 (by converting $K_{M}^{*}$ to moles of $\mathrm{H}_{2} \mathrm{O}_{2}$ using the reaction volume and $1 \mathrm{~g}$ of soil).

446

447

448

449

450

451

452

453

454

455

456

457

458

459

460

461

462

463

464

465

Under the described experimental conditions, the rate limiting steps among the

productive reactions were presumed to be substrate capture by the soil catalases (a component of $k_{1}$ ) and/or release from the soil matrix (a component of $k_{3}^{\prime}$ ). Non-productive degradation of $E_{\text {soil }}^{o x}\left(k_{2}\right)$ was assumed to be a minor reaction component, where $k_{3}^{\prime} \gg k_{2}(40-42)$. Therefore, under these total assumptions, the $k_{c a t}^{*} / K_{M}^{*}$ term effectively reduced to $\left(K_{H} / R T\right) k_{1} R_{S}$, and was expressed in simplified units of $\mathrm{gdw}^{-1} \mathrm{~s}^{-1}$ (through division by the reaction volume). In effect, these units were consistent with a rate constant for a second order reaction - albeit, in mass-based terms. Accordingly, the $k_{c a t}^{*} / K_{M}^{*}$ term $\left(\sim k_{1}\right)$ was interpreted as relating to the rates of substrate capture by the catalases (Diagram 2), which included acquisition of $\mathrm{H}_{2} \mathrm{O}_{2}$ and the first irreversible step of catalysis (formation of $E_{\text {soil }}^{o x}$ ). Similarly, the $K_{M}^{*}$ term reduced to $k_{3}^{\prime} / k_{1}\left(\mathrm{mM} \mathrm{g}^{-1}\right)$, or a ratio of the rates of product release over substrate capture, and was interpreted as the capacity of the soil to degrade $\mathrm{H}_{2} \mathrm{O}_{2}$. Thus, as per Diagram 2, the $k_{\text {cat }}^{*}$ term was interpreted as relating to the rates of gaseous $\mathrm{O}_{2}$ release.

\section{Michaelis-Menten Kinetics}

Michaelis-Menten kinetic studies were performed on (1) topsoils of BSCs obtained from areas of high (HD) and intermediate (ID) surface coverages (HD.Mojave.BSC.LabStation \&
ID.Mojave.BSC.LabStation, respectively), and (2) highly-irrigated CPP gardens soils

(CPP.BioTrek.Garden). Across the $K_{M}^{*}$ values (Figure 3A), CPP garden soils (210 $\pm 40 \mathrm{mM}$ ) 
exhibited an 2 and 5-fold greater capacity to degrade $\mathrm{H}_{2} \mathrm{O}_{2}$, per gram of soil, as compared to the BSCs (110 \pm 15 and $45 \pm 13 \mathrm{mM})$. Across the BSC samples, the HD-BSCs exhibited an $\sim 2$-fold greater capacity to degrade $\mathrm{H}_{2} \mathrm{O}_{2}$ per gram of soil $(p<0.05)$ than the ID-BSCs.

As displayed in Figure 3B, $k_{\text {cat }}^{*} / K_{M}^{*}$ values for CPP garden soils $\left(4.2 \times 10^{-3} \pm 0.9 \times 10^{-3} \mathrm{gdw}^{-1}\right.$ $\left.\mathrm{s}^{-1}\right)$ were $\sim 2-3$-fold higher than those of BSCs $\left(1.4 \times 10^{-3} \pm 0.2 \times 10^{-3}\right.$ and $1.9 \times 10^{-3} \pm 0.6 \times 10^{-3} \mathrm{gdw}^{-1} \mathrm{~s}^{-}$ $\left.{ }^{1}\right)$; while values across the BSCs were statistically equivalent ( $\left.p>0.05\right)$. This indicated that CPP garden soils exhibited the largest rates of substrate capture, whereas the rates across the BSCs were equivalent. Trends across the $k_{\text {cat }}^{*}$ values (Figure 3 C) indicated that CPP garden soils (27 \pm $\left.2 \mu \mathrm{kat}_{\mathrm{gdw}}{ }^{-1}\right)$ were $~ 6-10$-fold higher than the BSCs $\left(4.6 \pm 0.2\right.$ and $\left.2.6 \pm 0.2 \mu \mathrm{kat} \mathrm{gdw}^{-1}\right)$. Across the BSCs, $k_{\text {cat }}^{*}$ values for HD BSCs were $\sim 2$-fold higher $(\mathrm{p}<0.05)$ than those for ID BSCs. This indicated that CPP gardens soils exhibited the largest rates of product release. Across the BSCs, HD-BSCs displayed the largest rates of product release.

\section{Catalase Specific Activities}

Catalase SAs across several types of soil microbial communities were measured by VD

(Figures 4 and S2, Table S1); including BSCs, Alaskan permafrost, high-elevation permafrost, high-elevation arid soils, high-elevation garden soils, temperate garden soils, and temperate landscaped soils. Reaction conditions included 50 mM HEPES (pH 7.5) with 330 mM nonstabilized $\mathrm{H}_{2} \mathrm{O}_{2}$, or $1 \times$ PBS with $330 \mathrm{mM}$ stabilized $\mathrm{H}_{2} \mathrm{O}_{2}$; respectively referred to herein as HPS/NS and PBS/S. Trends across the SAs in HPS/NS (Figures 4 and S2) were as follows: CPP garden soils $\left(10 \pm 1 \mu \mathrm{kat} \mathrm{gdw}^{-1}\right)>$ BSCs measured in the field $\left(8.4 \pm 0.4 \mu \mathrm{kat}_{\mathrm{gdw}}{ }^{-1}\right)>\mathrm{dry}$ 
landscaped CPP soils ( 5-6 $\left.\mu \mathrm{kat} \mathrm{gdw}^{-1}\right)>$ BSCs measured in field station and formal laboratories

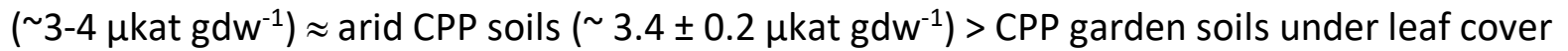
$\left(1.9 \pm 0.1 \mu \mathrm{kat} \mathrm{gdw}^{-1}\right)>$ Alaskan permafrost $\left(1.2 \pm 0.1 \mu \mathrm{kat} \mathrm{gdw}^{-1}\right)$

For the BSCs, the highest SAs were obtained from field samples analyzed immediately after collection $\left(7.2 \pm 0.4 \mu \mathrm{kat} \mathrm{g}^{-1}\right.$ or $\left.8.4 \pm 0.4 \mu \mathrm{kat}_{\mathrm{gdw}} \mathrm{g}^{-1}\right)$. After storage for $\sim 2$ days, SAs were 2-fold lower $\left(3.5 \pm 0.2 \mu \mathrm{kat} \mathrm{g}^{-1}\right)$, which indicated post-sampling degradation. After $\sim 2$ weeks of storage, measurements (in a formal laboratory) showed minimal further degradation (3.1 \pm 0.2 $\left.\mu k \mathrm{~g}^{-1}\right)$. The SAs for BSCs were additionally compared along the vertical column structure (Figure 3D), with the topsoils $\left(3.5 \pm 0.2 \mu \mathrm{kat}^{-1}\right)$ having $\sim 10$-fold higher SA values than the subsurface $\left(0.33 \pm 0.05 \mu k^{k} \mathrm{~g}^{-1}\right)$.

exhibited relatively lower SAs of $\leq 2.5 \mu \mathrm{kat} \mathrm{g}^{-1}$ (Figure 4). The lowest values were obtained from arid topsoils, which exhibited a range of $\sim 0.4-0.8 \mu \mathrm{kat} \mathrm{g}^{-1}$ (Tsokar, Khardung La, and Taglang La), and from permafrost samples (Tsokar), which exhibited $0.6 \pm 0.3 \mu \mathrm{kat} \mathrm{g}^{-1}$. Garden soils (Ladakh.Sumur) exhibited the highest value of $2.2 \pm 0.1 \mu \mathrm{kat} \mathrm{g}^{-1}$. Samples obtained from the slightly alkaline Panamik hot springs $\left(\mathrm{pH} \sim 8\right.$ ) yielded no VD rates (when at $<25^{\circ} \mathrm{C}$ ), likely due to inhibition by sulfide (43), despite the clear visual evidence of microbial mats. For the alkaline evaporates from Soda lake in the Mojave National Preserve (Figure 3E), SAs increased 12-fold between 1-3 cm ( 0.09-0.14 $\left.\mu \mathrm{kat} \mathrm{g}^{-1}\right)$ and $4 \mathrm{~cm}\left(1.7 \pm 0.3 \mu \mathrm{kat} \mathrm{g}^{-1}\right)$ along the compressed core, and then decreased $\sim 4$-fold at $5 \mathrm{~cm}\left(0.47 \pm 0.07 \mu \mathrm{kat} \mathrm{g}^{-1}\right)$. 
516 however, for the $33 \mathrm{ky}$ sample, SAs were higher at $22^{\circ} \mathrm{C}$ by a factor of $1.9 \pm 0.6(\mathrm{p}=0.019)$. copy number $\left.\mathrm{gdw}^{-1}\right)$, and 33 ky Alaskan permafrost $\left(2.0 \times 10^{5} \pm 0.1 \times 10^{5}\right.$ copy number $\left.\mathrm{gdw}^{-1}\right)(35$, regression across the standard curve provided good fits $\left(R^{2}=0.91\right)$, respective standard errors of 18 and $28 \%$ for the slope and intercept, and $1.1 \times 10^{4} 16 \mathrm{~S}$ rRNA gene copy number gdw ${ }^{-1}$ as the limit of detection (LOD). 
532 landscaped soils (CPP.Quad.DryPatch \& CPP.EnvDes.DryPatch), 107 for irregularly-irrigated soils (CPP.BioTrek.DryPatch), and $10^{6}$ for garden soils under substantial leaf cover. Across the microbial communities from high-elevation soils, biomass estimates (copy number $\mathrm{gdw}^{-1}$ ) were $\sim 10^{6-9}$ for garden soils (when assuming soil water contents of $\sim 70 \%$ or less; Ladakh.Sumur), $\sim 10^{4-5}$ for arid topsoils (Ladakh.Tsokar, Ladakh.KhardungLa, and Ladakh.TaglangLa), and 104 for

537 permafrost (Ladakh.Tsokar.PF). Bacterial abundances for garden soils were potentially high due 538 to exclusion of eukaryotic biomass. mass, and total soil mass), biomasses were only estimated in $\sim 10^{\mathrm{x}}$ increments (which amounted

542 to differences of $\geq 1.1 \mu \mathrm{kat}_{\mathrm{gdw}} \mathrm{gd}^{-1}$ between the estimates). In addition, biomasses were only 543 estimated using SAs obtained from field station or formal laboratory measurements (similar to 544 the standard curve). Catalase SAs for BSC subsurfaces (Figure 1D) did not follow the regression 545 trend (measured biomasses for HD-BSCs and ID-BSCs were $1.5 \times 10^{7} \pm 0.8 \times 10^{7}$ and $1.2 \times 10^{7} \pm$

$5460.5 \times 10^{7}$ copy number $\mathrm{g}^{-1}$, respectively (35)). As a result, the standard curve and biomass

547 estimates were restricted to topsoils and permafrost; or, to environmental samples that were

548 likely accustomed to appreciable native oxidative stresses prior to collection (as was

549 assumed/inferred for the topsoils due to continual aerobic and photosynthetic metabolism and 550 exposures to ultraviolet radiation; and for permafrost due to metagenomic and genomic lines 551 of evidence which show high abundances of genes associated with oxidative stress (45-47)). 


\section{Portable Devices and Field-Amenable Assays}

Low-cost, portable, and field-amenable devices were assembled to measure microbial catalase activities in soils and permafrost. Portability and field-applicability for VD were readily

557 demonstrated through experiments conducted in the field (Mojave National Preserve), temporary work station (Mogol Hostel, Ladakh, India), and field station laboratory (CSU Desert

559 Studies Center). Given the need for continual upright storage of the $\mathrm{O}_{2}$ Gas Sensor for EC, the

560 VD apparatus was better suited for field campaigns and travel. Measurements by VD were

561 rapid (<2 min per sample) and amenable to the analysis of large samples sets. In contrast,

562 measurements by EC exhibited appreciable lag times in the reactions, and required re-

563 equilibration of the sensor between runs. Nevertheless, for lower activity samples $(<0.2 \mu k a t$,

$564<12$ Units; 1-2 g sample), EC was more reliable, as was demonstrated with alkaline evaporate samples (however, a geochemical basis for the low degradation rates could not be ruled out).

To enact comparisons across measurements obtained during field campaigns, rates were barometrically adjusted to correct for the impacts of elevation, relative humidity, and temperature. For catalase SAs from high-elevation soil microbial communities, this prevented over-inflation by $\sim 1.5$-fold. To afford comparisons across spectral, electrochemical, and

571 physical techniques, displacement rates $\left(\mathrm{g} \mathrm{H}_{2} \mathrm{O}\right.$ displaced s$\left.{ }^{-1}\right)$ and electrochemical rates $\left(\% \mathrm{O}_{2}\right.$

$572 \mathrm{~min}^{-1}$ ) were transformed to molecular rates using SI units ( $\mu$ kat, or $\mu$ moles $\mathrm{H}_{2} \mathrm{O}_{2}$ consumed s${ }^{-1}$ ).

573 Such conversions are atypical for environmental catalases. 
Equivalent catalase SAs ( $p>0.05$ ) were obtained from VD and EC when using BSCs (in lab

576 station and field experiments); thereby directly correlating the displacement of water to the

577 electrochemical detection of gaseous $\mathrm{O}_{2}$. For permafrost and bacterial samples, the 2-fold

578 higher values from VD were suggestive of the presence of gaseous side products (e.g., $\mathrm{CO}_{2}$ and

$579 \mathrm{H}_{2}$ ) potentially formed from reactions (e.g., oxidation and homolytic fragmentations) between

$580 \quad \mathrm{H}_{2} \mathrm{O}_{2}$ and cellular carbohydrates (48). While speculative, these results were suggestive of

581 extra/intracellular carbohydrates from ice-laden permafrost and aqueous bacterial cultures

582 (50v1 extract) being more prone to degradation by $\mathrm{H}_{2} \mathrm{O}_{2}$ than those from the desert microbial

583 communities (BSCs).

Across the tested buffers and substrates, the trends suggested that microbial catalases 

samples, CPP garden soils exhibited the highest capacity to degrade $\mathrm{H}_{2} \mathrm{O}_{2}\left(K_{M}^{*}\right)$, fastest rate of substrate capture $\left(k_{c a t}^{*} / K_{M}^{*}\right)$, and fastest rate of gaseous product release $\left(k_{c a t}^{*}\right)$. As per our soil catalase model, these trends were likely the result of high microbial abundances, rather than major differences in the intrinsic rate constants (for the catalase community). As per Equation $\mathrm{gdw})$ and directly raise the $k_{c a t}^{*}$ and $k_{c a t}^{*} / K_{M}^{*}$ terms, since $k_{c a t}^{*}=\left(K_{H} / R T\right) k_{3}^{\prime} R_{s}$. To obtain upper estimates of $R_{S}$, therefore, we assumed that (1) $k_{c a t}^{*} / K_{M}^{*}$ was approximately equal to $\left(K_{H} / R T\right) k_{1} R_{s}$ when $k_{3}^{\prime} \gg k_{2}$, (2) values for $K_{H}\left(756\right.$ atm $\left.\mathrm{M}^{-1}\right)$ were roughly similar across the soil suspensions, (3) rate constants for bimolecular reactions in the soil/biological suspensions were reduced $\sim 100$-fold due to viscosity changes (49), and (4) commensurate $\sim 100$-fold reductions in the representative and diffusion-limited $k_{\text {cat }} / K_{M}$ term $\left(\sim 10^{7} \mathrm{M}^{-1} \mathrm{~s}^{-1}\right)$ for soluble catalases (in classical Michaelis-Menten kinetics, $k_{\text {cat }} / K_{M} \approx k_{1}$ when $k_{2} \gg k_{-1}$ ). 
618 larger $K_{M}^{*}$ values $\left(\sim k_{3}^{\prime} / k_{1}\right)$ for CPP garden soils were not due to major changes in substrate acquisition, but rather the result of a $\sim 2$-fold higher rate of product formation $\left(k_{3}^{\prime}\right)$.

620

621

622

623

624

625

626

627

628

629

630

631

632

633

634

635

636

637

638

639

When comparing the HD and ID-BSCs, the HD-BSCs exhibited a higher capacity to

degrade $\mathrm{H}_{2} \mathrm{O}_{2}\left(K_{M}^{*}\right)$, an equivalent rate of substrate capture $\left(k_{c a t}^{*} / K_{M}^{*}\right)$, and faster rate of gaseous product release $\left(k_{c a t}^{*}\right)$. The similar $k_{c a t}^{*} / K_{M}^{*}$ values supported the rates of substrate capture $\left(k_{1}\right)$ being diffusion-limited in the soil suspensions (as was assumed in the calculation of $\left.R_{S}\right)$. Trends across the rate constants again implied that the $\sim 2$-fold larger $K_{M}^{*}\left(\sim k_{3}^{\prime} / k_{1}\right)$ for HDBSCs was the result of the $\sim 2$-fold higher rates of product formation $\left(k_{3}^{\prime}\right)$.

\section{Trends in Catalase Specific Activities}

Comparisons across differing soils and permafrost supported the use of catalase SAs

(Figure 4) as markers for microbial biomass and indicators for biological activity. For microbial communities from arid soils, catalase SAs per soil mass $\left(\mu \mathrm{kat} \mathrm{gdw}^{-1}, \mu \mathrm{kat}^{-1}\right.$ ) from high elevation Ladakh topsoils (Tsokar, Khardung La, and Taglang La; 4500-5500 m) were 10-fold lower than those from BSC topsoils, which were sampled at much lower elevations (450-685 m). As per our model, these differences corresponded to lower microbial biomasses of $\sim 10^{4-5}$ copy number gdw ${ }^{-1}$ for Ladakh topsoils (calculated value), as compared to $\sim 10^{7}$ copy number $\mathrm{gdw}^{-1}$ for BSCs (measured value). For permafrost, catalase SAs obtained at 4 and $22{ }^{\circ} \mathrm{C}$ amounted to activation energies of $9-25 \mathrm{~kJ} / \mathrm{mol}$, which was consistent with the literature values for purified catalases $(39,51)$. Catalase SAs $\left(0.06-1.4 \mu k a t \mathrm{gdw}^{-1}\right.$ or $\left.\mu \mathrm{kat} \mathrm{g}^{-1}\right)$ were also measurable in samples arising from anaerobic and/or oxygen-limited environments, including 
640

641

642

643

644

645

646

647

648

649

650

651

652

653

654

655

656

657

658

659

660

661

BSC subsurfaces, Alaskan permafrost, Ladakh permafrost, and Soda lake alkaline evaporates.

Hence, these results suggested that the anaerobic and/or oxygen-tolerant microbial

communities experience oxidative stress due to the presence of active catalase enzymes.

\section{Catalases and Microbial Biomass}

To obtain further insights into the relationships between catalase activity and biomass, the values of $R_{S}$ and SA were normalized to 16S rRNA gene copy numbers per gram dry weight (copy number $\mathrm{gdw}^{-1}$ ). Conversions were conducted using measured 16S rRNA gene copy numbers for BSC topsoils, BSC subsurfaces, and Alaskan permafrost; while calculated values were used for CPP and Ladakh topsoils. For $R_{S}$, re-expression provided catalase abundances of 250 and 1200 zeptomoles (zmol) per 16S rRNA gene copy number for HD- and ID-BSCs, and 0.004 to 4 zmol copy number ${ }^{-1}$ for CPP garden soils (when assuming $1 \times 10^{10-13}$ copy number gdw ${ }^{-}$

$\left.{ }^{1}\right)$. Considering an average of two $16 \mathrm{~S}$ rRNA gene copy numbers per cell $(52,53)$, and a representative cellular volume of $\sim 1 \mu \mathrm{m}^{3}$ for soil microbes $(54,55)$, these values amounted to catalase concentrations of $\sim 0.5 \mathrm{mM}$ for HD-BSCs, $\sim 2 \mathrm{mM}$ for ID-BSCs, and $\sim 0.008-8 \mu \mathrm{M}$ for CPP garden soils. In context, cultured $E$. coli cells $\left(\sim 0.6 \mu \mathrm{m}^{3}\right)$ reportedly contain $\sim 0.03 \mathrm{mM}$ catalase when exposed to mild external oxidative stress $\left(100 \mu \mathrm{M}\right.$ exogenous $\left.\mathrm{H}_{2} \mathrm{O}_{2}\right)$, and up to $\sim 0.4 \mathrm{mM}$ when subjective to moderate intracellular oxidative stress $\left(50 \mu \mathrm{M}\right.$ intracellular $\left.\mathrm{H}_{2} \mathrm{O}_{2}\right)(56-58)$. Therefore, consistent with these comparisons is the assessment that microbial communities from BSCs experience substantially higher degrees of native oxidative stress and, consequently, possess substantially higher basal concentrations of intracellular catalase $\left(\leq 10^{5}\right.$-fold higher concentrations than garden soils communities, as per these estimates). 
672 potentially included background radiation dosages accumulated over geological time scales (59,

673 60). For high-elevation arid topsoil communities, stresses included the accumulated dosages

674 from intense UV exposures, where UV-A doses are 10x greater than sea level (33). And, for

675 topsoil communities under leaf litter, stresses included persistent exposures to $\mathrm{H}_{2} \mathrm{O}_{2}$ (and other

676 reactive oxygen species) formed during plant-matter degradation (61-63). 
oxygen species for BSC topsoil communities included ultraviolet radiation exposures, photosynthesis, and aerobic respiration (4-6).

\section{Implications for Microbial Ecology}

In the context of microbial ecology, the differing profiles across $k_{3}^{\prime}, R_{s}$ per biomass, and SAs per biomass served as indicators for changes in catalase community structure (e.g, differences in $1^{\circ}$ structure, metal cofactor, and class) and, by extension, microbial community structure. For instance, when comparing HD-BSCs to CPP garden soils, the $\sim 2$-fold lower values for $k_{3}^{\prime}, \geq 10^{5}$-fold higher values for $R_{s}$ per biomass, and $\sim 10^{4}$-fold higher SAs per biomass were consistent with broad phylum-level taxonomic changes in the community structure. In support, phylogenetic studies show that HD-BSCs are numerically dominated by Cyanobacteria and Proteobacteria (35), while garden soils are typically dominated by Actinobacteria, Proteobacteria, and Firmicutes $(64,65)$. When comparing HD-BSCs to ID-BSCs, however, the mild differences in kinetics (e.g. $\sim 2$-fold higher values for $k_{3}^{\prime}, \sim 5$-fold lower values for $R_{s}$ per biomass, and 3-fold lower SAs per biomass) were consistent with moderate genus-level changes across the Cyanobacteria and Proteobacteria, as phylum distributions were equivalent in these samples (35). In support, comparisons conducted for this report show that the HDBSCs contain $\sim 1.5$-fold lower abundances of Phormidium, $\sim 1.7$-fold higher abundances of an unidentified genus from Nostocophycideae, and a 2-fold lower abundance of an unidentified genus from Oxalobacteraceae (when using a Benjamini-Hochberg critical value of $p<0.0099$, false discovery rate of 0.50$)$. Similarly, for Alaskan permafrost, the $\sim 5$-fold increase in catalase SAs per biomass across the chronosequence (19 vs. 33 ky samples) were attributed to the 
706

707

708

709

710

711

712

713

714

715

716

717

718

719

720

721

722

723

724

725

726

727

728

729

730

presence of cold-adapted catalases arising from broad phylum-level changes in community

structure with Acidobacteria, Proteobacteria, and Bacteroidetes dominating the 19 ky samples, and Firmicutes dominating the 33 ky samples (46).

\section{Conclusions}

In conclusion, the combined kinetic trends described in this report support the hypothesis that microbial communities which experience higher degrees of oxidative stress possess higher basal concentrations of intracellular catalase $\left(R_{S}\right.$ per copy number $)$ and catalase specific activities per biomass (SAs per copy number), and that differing kinetic profiles across catalase communities are indicative of phylogenetic changes in community structure. In addition, we aptly demonstrate that volume displacement serves as a cost-effective, simple, and field-amenable method for measuring catalase kinetics across differing environmental samples. Further, this method is suitable for scientists and educators from all disciplines, irrespective of budgetary concerns, or familiarity with chemical kinetics. Thus, as a biochemical tool for microbial ecology, this assay and kinetic treatment represents a robust means to detect and quantify the presence and abundance of active microbial communities in soils and permafrost.

\section{Author Contributions}

All authors contributed to the acquisition and analysis of the data. Contributions to critical reports/revisions of the work were obtained from MC, EM, JC, NR, SG, and RM; and all contributors approved the manuscript, and agreed to be accountable for the work. The primary investigator and corresponding author is RM. Michaelis-Menten analyses, specific activity measurements of BSCs, comparative controls, and development of barometric calculations were performed by MC. Critical initial measurements and field work with VD were 
731 conducted by EM. Comparisons of buffers and substrate formulations on the specific activities

732 of CPP soils were conducted by JC and NR. Permafrost measurements by VD and EC were

733 conducted by SG.

734

\section{Acknowledgments}

736 This work was funded through the NASA Astrobiology Minority Institutional Research

737 Support program (MIRS), and the California State University (CSU) Math and Science Teacher

738 Initiative (MSTI). We acknowledge the contributions of Nicholas Cooper who performed field-

739 based measurements of BSCs by EC, as well comparative laboratory controls. Catalase-based

740 field work was conducted as part of the NASA/CSU Spaceward Bound pre-service teacher

741 training program in the Mojave National Preserve (2016), and as part of a Spaceward Bound

742 field campaign in Ladakh, India (2017). Scientific Research and Collecting Permits from the

743 National Park Service for the Mojave National Preserve included MOJA- 2011-SCI-0048, MOJA-

744 2013-SCl-0004, and MOJA-2016-SCl-0002. Requisite clearances and permits were obtained

745 from the Office of Chief Wildlife Warden of Ladakh, Government of India for work in 2017. 


\section{References}

1. Imlay, J. A. 2013. The molecular mechanisms and physiological consequences of oxidative stress: lessons from a model bacterium. Nature. Rev. Microbiol. 11:443-454.

2. Gambino, M., and F. Cappitelli. 2016. Mini-review: Biofilm responses to oxidative stress. Biofouling 32:167-178.

3. Gębicka, L., and J. Krych-Madej. 2019. The role of catalases in the prevention/promotion of oxidative stress. J. Inorg. Biochem. 197:110699.

4. Potts, M. 1994. Desiccation tolerance of prokaryotes. Microbiol Rev 58:755.

5. Krumova, K., and G. Cosa. 2016. Overview of Reactive Oxygen Species, p. 1-21, Singlet Oxygen: Applications in Biosciences and Nanosciences, vol. 1. The Royal Society of Chemistry.

6. Georgiou, C. D., H. J. Sun, C. P. McKay, K. Grintzalis, I. Papapostolou, D. Zisimopoulos, K. Panagiotidis, G. Zhang, E. Koutsopoulou, and G. E. Christidis. 2015. Evidence for photochemical production of reactive oxygen species in desert soils. Nature Commun. 6:1-11.

7. Abbott, D. A., E. Suir, G.-H. Duong, E. de Hulster, J. T. Pronk, and A. J. van Maris. 2009. Catalase overexpression reduces lactic acid-induced oxidative stress in Saccharomyces cerevisiae. Appl. Environ. Microbiol. 75:2320-2325.

8. Farr, S. B., and T. Kogoma. 1991. Oxidative stress responses in Escherichia coli and Salmonella typhimurium. Microbiol Rev 55:561-585.

9. McCoy, K., I. Derecho, T. Wong, H. Tran, T. Huynh, M. La Duc, K. Venkateswaran, and R. Mogul. 2012. Insights into the Extremotolerance of Acinetobacter radioresistens 50v1, a Gram-Negative Bacterium Isolated from the Mars Odyssey Spacecraft. Astrobiology 12:854-862.

10. Amo, T., H. Atomi, and T. Imanaka. 2002. Unique presence of a manganese catalase in a hyperthermophilic archaeon, Pyrobaculum calidifontis VA1. J. Bacteriol. 184:3305-3312.

11. Chelikani, P., I. Fita, and P. C. Loewen. 2004. Diversity of structures and properties among catalases. Cell. Mol. Life Sci. 61:192-208.

12. Whittaker, J. W. 2012. Non-heme manganese catalase-the 'other'catalase. Archives Biochem. Biophysics 525:111-120.

13. Hernandez-Ruiz, J., M. B. Arnao, A. N. Hiner, F. Garcia-Cánovas, and M. Acosta. 2001. Catalase-like activity of horseradish peroxidase: relationship to enzyme inactivation by $\mathrm{H}_{2} \mathrm{O}_{2}$. Biochem. J. 354:107-114.

14. Kato, S., T. Ueno, S. Fukuzumi, and Y. Watanabe. 2004. Catalase reaction by myoglobin mutants and native catalase mechanistic investigation by kinetic isotope effect. J. Biol. Chem. 279:52376-52381.

15. Vainshtein, B. K., W. R. Melik-Adamyan, V. V. Barynin, A. A. Vagin, and A. I. Grebenko. 1981. Threedimensional structure of the enzyme catalase. Nature 293:411-412.

16. Nelson, D. L., and M. M. Cox. 2005. Lehninger Principles of Biochemistry. W. H. Freeman.

17. Alfonso-Prieto, M., X. Biarnés, P. Vidossich, and C. Rovira. 2009. The molecular mechanism of the catalase reaction. J. Am. Chem. Soc. 131:11751-11761.

18. Kirkman, H. N., and G. F. Gaetani. 2007. Mammalian catalase: a venerable enzyme with new mysteries. Trends Biochem. Sci. 32:44-50.

19. Jones, P., and A. Suggett. 1968. The catalase-hydrogen peroxide system. A theoretical appraisal of the mechanism of catalase action. Biochem. J. 110:621-629.

20. Siegbahn, P. E. 2001. A quantum chemical study of the mechanism of manganese catalase. Theor. Chem. Accounts 105:197-206.

21. Stpniewska, Z., A. Wolińska, and J. Ziomek. 2009. Response of soil catalase activity to chromium contamination. J. Environ. Sci. 21:1142-1147.

22. Zhang, W., S. Liu, M. Zhang, Y. Li, K. Sheng, and Z. Xu. 2019. Phyllostachys edulis (moso bamboo) rhizosphere increasing soil microbial activity rather than biomass. J. Soils Sed. 19:2913-2926. 
23. Trasar-Cepeda, C., F. Camiña, M. C. Leirós, and F. Gil-Sotres. 1999. An improved method to measure catalase activity in soils. Soil Biol. Biochem. 31:483-485.

24. Zhang, L., Z. Wu, L. Chen, Y. Jiang, and D. Li. 2009. Kinetics of catalase and dehydrogenase in main soils of Northeast China under different soil moisture conditions. Agricultural J. 4:113-120.

25. Shang, Z., L. Zhang, Z. Wu, P. Gong, D. Li, P. Zhu, and H. Gao. 2012. The activity and kinetic parameters of oxidoreductases in phaeozem in response to long-term fertiliser management. J. Soil Sci. Plant Nut. 12:597-607.

26. Weigand, S., K. Auerswald, and T. Beck. 1995. Microbial biomass in agricultural topsoils after 6 years of bare fallow. Bio. Fert. Soils 19:129-134.

27. Domsch, K., T. Beck, J. Anderson, B. Söderström, D. Parkinson, and G. Trolldenier. 1979. A comparison of methods for soil microbial population and biomass studies. Zeitschrift für Pflanzenernährung und Bodenkunde 142:520-533.

28. Weetall, H., N. Weliky, and S. Vango. 1965. Detection of Micro-Organisms in Soil by Their Catalatic Activity. Nature 206:1019-1021.

29. Luís, A., M. G. Ortega, A. L. Lopez, and J. L. Gorge. 1977. A more sensitive modification of the catalase assay with the Clark oxygen electrode: application to the kinetic study of the pea leaf enzyme. Anal. Biochem. 80:409-415.

30. Montavon, P., K. R. Kukic, and K. Bortlik. 2007. A simple method to measure effective catalase activities: optimization, validation, and application in green coffee. Anal. Biochem. 360:207-215.

31. Guwy, A., S. Martin, F. Hawkes, and D. Hawkes. 1999. Catalase activity measurements in suspended aerobic biomass and soil samples. Enzyme Microbial Technol. 25:669-676.

32. Mateos, M. P., and S. G. Carcedo. 1985. Effect of fractionation on location of enzyme activities in soil structural units. Bio. Fert. Soils 1:153-159.

33. Pandey, S., J. Clarke, P. Nema, R. Bonaccorsi, S. Som, M. Sharma, B. Phartiyal, S. Rajamani, R. Mogul, and J. Martin-Torres. 2020. Ladakh: Diverse, high-altitude extreme environments for off-earth analogue and astrobiology research. Int. J. Astrobiology 19:78-98.

34. Berberan-Santos, M. N., E. N. Bodunov, and L. Pogliani. 1997. On the barometric formula. Am. J. Physics 65:404-412.

35. Mogul, R., P. Vaishampayan, M. Bashir, C. P. McKay, K. Schubert, R. Bornaccorsi, E. Gomez, S. Tharayil, G. Payton, J. Capra, J. Andaya, L. Bacon, E. Bargoma, D. Black, K. Boos, M. Brant, M. Chabot, D. Chau, J. Cisneros, G. Chu, J. Curnutt, J. DiMizio, C. Engelbrecht, C. Gott, R. Harnoto, R. Hovanesian, S. Johnson, B. Lavergne, G. Martinez, P. Mans, E. Morales, A. Oei, G. Peplow, R. Piaget, N. Ponce, E. Renteria, V. Rodriguez, J. Rodriguez, M. Santander, K. Sarmiento, A. Scheppelmann, G. Schroter, D. Sexton, J. Stephenson, K. Symer, T. Russo-Tait, B. Weigel, and M. B. Wilhelm. 2017. Microbial Community and Biochemical Dynamics of Biological Soil Crusts across a Gradient of Surface Coverage in the Central Mojave Desert. Front Microbiol 8:1974.

36. Muster, N., I. Derecho, F. Dallal, R. Alvarez, K. McCoy, and R. Mogul. 2015. Purification, Biochemical Characterization, and Implications of an Alkali-Tolerant Catalase from the Spacecraft-Associated and Oxidation-Resistant Acinetobacter gyllenbergii 2P01AA. Astrobiology 15:291-300.

37. Clark, J. H., C. W. Jones, and M. J. Braithwaite. 2007. Applications of Hydrogen Peroxide and Derivatives. Royal Society of Chemistry.

38. Schumb, W. 1957. Stabilization of concentrated solutions of hydrogen peroxide. Indust. Eng. Chem. 49:1759-1762.

39. Hochman, A., and A. Shemesh. 1987. Purification and characterization of a catalase-peroxidase from the photosynthetic bacterium Rhodopseudomonas capsulata. J. Biol. Chem. 262:6871-6876.

40. Kirkman, H. N., M. Rolfo, A. M. Ferraris, and G. F. Gaetani. 1999. Mechanisms of protection of catalase by NADPH Kinetics and stoichiometry. J. Biol. Chem. 274:13908-13914. 
41. Obinger, C., M. Maj, P. Nicholls, and P. Loewen. 1997. Activity, Peroxide Compound Formation, and Heme d Synthesis in Escherichia coli HPII Catalase. Archives Biochem. Biophysics 342:58-67.

42. Gębicka, L., D. Metodiewa, and J. L. Gębicki. 1989. Pulse Radiolysis of Catalase in Solution. I. Reactions of O-2 with Catalase and Its Compound I. Int. J. Rad. Bio. 55:45-50.

43. Corpas, F. J., J. B. Barroso, S. González-Gordo, M. A. Muñoz-Vargas, and J. M. Palma. 2019. Hydrogen sulfide: A novel component in Arabidopsis peroxisomes which triggers catalase inhibition. J. Integr. Plant Bio. 61:871-883.

44. Burkert, A., T. A. Douglas, M. P. Waldrop, and R. Mackelprang. 2019. Changes in the active, dead, and dormant microbial community structure across a Pleistocene permafrost chronosequence. Appl. Environ. Microbiol. 85:e02646-02618.

45. Rivkina, E., L. Petrovskaya, T. Vishnivetskaya, K. Krivushin, L. Shmakova, M. Tutukina, A. Meyers, and F. Kondrashov. 2016. Metagenomic analyses of the late Pleistocene permafrost-additional tools for reconstruction of environmental conditions. Biogeosciences 13.

46. Mackelprang, R., A. Burkert, M. Haw, T. Mahendrarajah, C. H. Conaway, T. A. Douglas, and M. P. Waldrop. 2017. Microbial survival strategies in ancient permafrost: insights from metagenomics. ISME J. 11:2305-2318.

47. Raymond-Bouchard, I., J. Goordial, Y. Zolotarov, J. Ronholm, M. Stromvik, C. Bakermans, and L. G. Whyte. 2018. Conserved genomic and amino acid traits of cold adaptation in subzero-growing Arctic permafrost bacteria. FEMS Microbiol. Ecol. 94:fiy023.

48. Payne, J. H., and L. Foster. 1945. The Action of Hydrogen Peroxide on Carbohydrates1. J. Am. Chem. Soc. 67:1654-1656.

49. Strother, G., and E. Ackerman. 1961. Physical factors influencing catalase rate constants. Biochimica et Biophysica Acta 47:317-326.

50. Kengen, S. W., F. J. Bikker, W. R. Hagen, W. M. Vos, and J. Oost. 2001. Characterization of a catalase-peroxidase from the hyperthermophilic archaeon Archaeoglobus fulgidus. Extremophiles 5:323-332.

51. Wang, W., M. Sun, W. Liu, and B. Zhang. 2008. Purification and characterization of a psychrophilic catalase from Antarctic Bacillus. Can. J. Microbiol. 54:823-828.

52. Zhang, A. N., Y. Mao, and T. Zhang. 2016. Development of Quantitative Real-time PCR Assays for Different Clades of "Candidatus Accumulibacter". 6:23993.

53. Mise, K., R. Maruyama, Y. Miyabara, T. Kunito, K. Senoo, and S. Otsuka. 2020. Time-series analysis of phosphorus-depleted microbial communities in carbon/nitrogen-amended soils. Appl. Soil Ecol. 145.

54. Hu, C., D. Zhang, Z. Huang, and Y. Liu. 2003. The vertical microdistribution of cyanobacteria and green algae within desert crusts and the development of the algal crusts. Plant and Soil 257:97-111.

55. Brient, L., M. Lengronne, E. Bertrand, D. Rolland, A. Sipel, D. Steinmann, I. Baudin, M. Legeas, B. Le Rouzic, and M. Bormans. 2008. A phycocyanin probe as a tool for monitoring cyanobacteria in freshwater bodies. J. Environ. Monit. 10:248-255.

56. González-Flecha, B., and B. Demple. 1994. Intracellular generation of superoxide as a by-product of Vibrio harveyi luciferase expressed in Escherichia coli. J. Bacteriol. 176:2293-2299.

57. González-Flecha, B., and B. Demple. 1995. Metabolic sources of hydrogen peroxide in aerobically growing Escherichia coli. J. Biol. Chem. 270:13681-13687.

58. Kubitschek, H. 1990. Cell volume increase in Escherichia coli after shifts to richer media. J. Bacteriol. 172:94-101.

59. Altshuler, I., J. Goordial, and L. G. Whyte. 2017. Microbial life in permafrost, p. 153-179, Psychrophiles: from biodiversity to biotechnology. Springer.

60. Mackelprang, R., S. R. Saleska, C. S. Jacobsen, J. K. Jansson, and N. Taş. 2016. Permafrost metaomics and climate change. Annu. Rev. Earth Planet. Sci. 44:439-462. 
61. Grigutytė, R., J. Nimptsch, L. Manusadžianas, and S. Pflugmacher. 2009. Response of oxidative stress enzymes in charophyte Nitellopsis obtusa exposed to allochthonous leaf extracts from beech Fagus sylvatica. Biologija 55:142-149.

62. Janusz, G., A. Pawlik, J. Sulej, U. Swiderska-Burek, A. Jarosz-Wilkolazka, and A. Paszczynski. 2017. Lignin degradation: microorganisms, enzymes involved, genomes analysis and evolution. FEMS Microbiol Rev 41:941-962.

63. Schoenherr, S., M. Ebrahimi, and P. Czermak. 2018. Lignin Degradation Processes and the Purification of Valuable Products. InTech.

64. Kim, M., E. Heo, H. Kang, and J. Adams. 2013. Changes in soil bacterial community structure with increasing disturbance frequency. Microbial Ecol. 66:171-181.

65. Maksimova, A., M. Kuznetsova, A. Krivtsov, and V. Demakov. 2016. Changes in soil microbiota under the effect of acrylonitrile in a model experiment. Russian J. Ecol. 47:519-525. 


\section{Figure Legends}

902

903

904

905

906

907

908

909

910

911

912

913

914

915

916

917

918

919

920

921

922

923

924

925

926

927

928

929

930

931

932

933

934

935

936

937

938

Figure 1. Kinetics and Michaelis-Menten analyses of soil catalase activities using volume displacement: (A) Temporal change in the mass of displaced water using highly irrigated garden soils (CPP.BioTrek.Garden), topsoils of biological soil crusts (BSCs obtained from areas of high surface density (Mojave.BSC.HD.Top), and 33 ky permafrost (Alaska.PF.33ky; 35k8C); errors bars represent the standard deviation $(n=3)$ and, for display purposes, trendlines for garden soils were estimated using psuedo-first order kinetics $\left([B]=[A]_{0}\left(1-e^{-k t}\right)\right.$; where $[A]_{0}$ and $k$ were artificially set at $15 \mathrm{~g}$ and $\left.0.014 \mathrm{~s}^{-1}\right)$. (B) Impact of substrate concentration (50-700 mM) on the catalase activities for BSC topsoils, where linear regression of the rate plots from 15-75 s provided $R^{2} \geq 0.99$. (C) Michaelis-Menten analyses for garden soils (left $y$-axis), and biological soil crusts (right y-axis) sampled from sites of high (HD) and intermediate (ID) surface densities; specific activities were expressed as $\mu$ kat per gram dry weight ( $\mu \mathrm{kat} \mathrm{gdw}^{-1}$ ), errors bars represent the standard deviation $(n=3)$, and fits to the data were obtained using Equation 8. (D) Standard curve (black squares; $R^{2}=0.91$ ) representing relationship between catalase specific activities ( $\mu$ kat per gram dry weight; $\mu k^{2} \mathrm{gdw}^{-1}$ ) and rRNA gene copy numbers (log copy number) using HD- and ID-BSCs (Mojave.BSC.HD.Top.CPP, Mojave.BSC.HD.Top.DSC, and Mojave.BSC.ID.Top.DSC), and 19 and 33 ky Alaskan permafrost (Alaska.PF.33ky and Alaska.PF.19ky); error bars along both axes represent the standard error $(n=3), B S C$ subsurfaces are shown for comparison (gray circles), the $10^{x}$ labels represent probable biomass increments, and estimates of biomass (open circles) for Cal Poly Pomona (CPP) and Ladakh soils are listed (italics) in respective order.

Figure 2. Comparison of catalase specific activities as measured by volume displacement (VD), electrochemical detection (EC), and ultraviolet absorption (UV), where specific activities are expressed as $\mu \mathrm{kat} \mathrm{mg}^{-1}$ for bovine liver catalase (left $\mathrm{y}$-axis) and as $\mu \mathrm{kat}^{-1} \mathrm{X}^{-1}$ (right $\mathrm{y}$-axis) for a clarified extract of $A$. radioresistens 50v1 $(X=m g)$, topsoils of biological soil crusts (BSCs) $(X=g)$, and permafrost $(X=g)$; error bars represent the standard deviation $(n \geq 3)$, and all assays were conducted in $50 \mathrm{mM}$ HEPES ( $\mathrm{pH}$ 7.5) using non-stabilized hydrogen peroxide, except for the BSC field assays which used stabilized hydrogen peroxide, and permafrost assays which used PBS.

Figure 3. Trends across soil catalase kinetics and specific activities where statistical comparisons are marked ( $\left.{ }^{*} p<0.05 ;{ }^{x}>0.05\right)$ : Comparison of the Michaelis-Menten kinetic parameters for
(A) $K_{M}^{*}$,
(B) $k_{\text {cat }}^{*} / K_{M}^{*}$,
(C) and $k_{\text {cat }}^{*}$ across highly irrigated garden soils (CPP GS;

CPP.BioTrek.Garden), and topsoils of biological soil crusts (BSCs) sampled from sites of high (HD-BSC; BSC.HD.Mojave.Lab) and intermediate (ID-BSC; BSC.ID.Mojave.Lab) surface densities; rates for CPP GS and HD-BSC were measured in triplicate ( $n=1$ for ID-BSC), and error bars represent the standard error of the regression. (D) Comparison of specific activities for HD-BSCs 
along the vertical column structure (topsoil vs. subsurface $=$ top vs. sub) where specific activities are expressed as $\mu$ kat per total soil mass (left $y$-axis; $\mu$ kat $\mathrm{g}^{-1}$ ) and fkat per 16S rRNA gene copy number (right y-axis; fkat copy number ${ }^{-1}$ ); error bars represent the propagated error $(n=3)$. (E) Change in specific activities $\left(\mu k^{2} \mathrm{~g}^{-1}\right)$ along a depth profile for a compressed dry lake bed core; error bars represent the standard deviation $(n=2)$. (F) Comparison of specific activities of 19 ky and 33 ky permafrost (Alaska.PF.33ky \& Alaska.PF.19ky) measured at 4 and $22{ }^{\circ} \mathrm{C}$, and

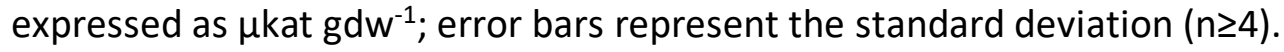

Figure 4. Comparison of barometrically adjusted catalase specific activities across differing soils (Table S1) expressed in SI units of $\mu$ kat per gram dry weight (bottom $\mathrm{x}$-axis; $\mu \mathrm{kat}_{\mathrm{gdw}} \mathrm{w}^{-1}$ ) and typical enzymology terms of Units per gram dry weight (top x-axis; Units gdw ${ }^{-1}$ ), with all Ladakh samples being expressed per total soil mass $\left(\mathrm{g}^{-1}\right)$; measurements listed in the top panel were obtained in 1x PBS and $330 \mathrm{mM}(1 \% \mathrm{w} / \mathrm{w})$ stabilized hydrogen peroxide, measurements listed in the bottom panel were obtained in $50 \mathrm{mM}$ HEPES ( $\mathrm{pH} 7.5)$ and $330 \mathrm{mM}(1 \% \mathrm{w} / \mathrm{w})$ nonstabilized hydrogen peroxide, all error bars represent the standard deviation $(n \geq 3)$, sampling site elevations are given in parentheses, and elevations for measurements were $241 \mathrm{~m}$ (CPP.X soils, Mojave.HD.BSC.Top.CPP, \& Alaska.PF.X), 284 m (Mojave.BSC.HD.Top.Field, Mojave.BSC.HD/ID.Top.DSC, \& Mojave.BSC.HD.Top/Sub.DSC), and 3300 m (Ladakh.X soils).

Figure 5. Comparison of specific activity (SA) values expressed per biomass (top $x$-axis; bars) and soil mass (bottom x-axis; black circles), where SAs per biomass are expressed in units of fkat per 16S rRNA gene copy number (fkat copy number ${ }^{-1}$ ) and SAs per soil mass are expressed

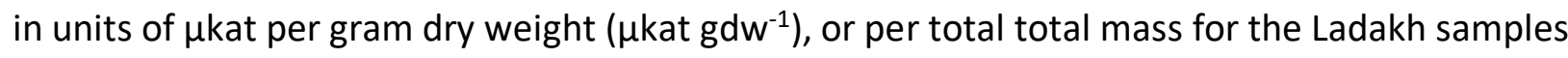
( $\left.\mu k^{k} \mathrm{~g}^{-1}\right)$; soil samples (y-axis) are listed in order of increasing SA per soil mass (top to bottom), arrows denote measured 16S rRNA copy number values (with all others being calculated), dotted line represents the trend, and error bars represent the standard deviation for the

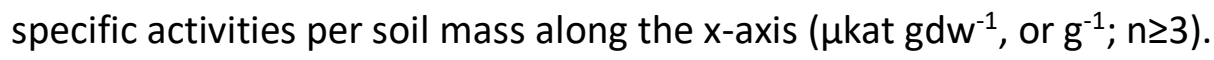

Supplementary Figure 1. Differing configurations and components of the catalase assay devices displaying ( $A$ ) one- and two-hole stoppers with threaded tubing, (B) sequential connections of the mixing, displacement, and collection chambers in the VD device (left to right), (C) batteryoperated mixer and scale for VD, (D) EC device with a direct connection between the mixing chamber and sensor, and (E) example field analysis.

Supplementary Figure 2. Impacts of (A) buffer type (HEPES vs. PBS) and (B) substrate formulation (stabilized vs. non-stabilized hydrogen peroxide) on the catalase specific activities, where soil samples are arranged (left to right) from highly irrigated (CPP.BioTrek.Garden) to infrequently irrigated (CPP.Env.Design.DryPatch) or arid soils (Mojave.BSC.Field), and low 
bioRxiv preprint doi: https://doi.org/10.1101/2020.06.11.147595; this version posted June 12, 2020. The copyright holder for this preprint (which was not certified by peer review) is the author/funder. All rights reserved. No reuse allowed without permission.

977 activity Alaskan permafrost (35k9B) is included in the inset plot; specific activities (columns) are

978 expressed as $\mu \mathrm{kat}_{\mathrm{gdw}} \mathrm{gl}^{-1}$, errors bars represent the propagated error $(\mathrm{n}=3)$, and statistical

979 comparisons are marked $\left(* p<0.05 ; x_{p}>0.05\right)$. 
Figure 1.

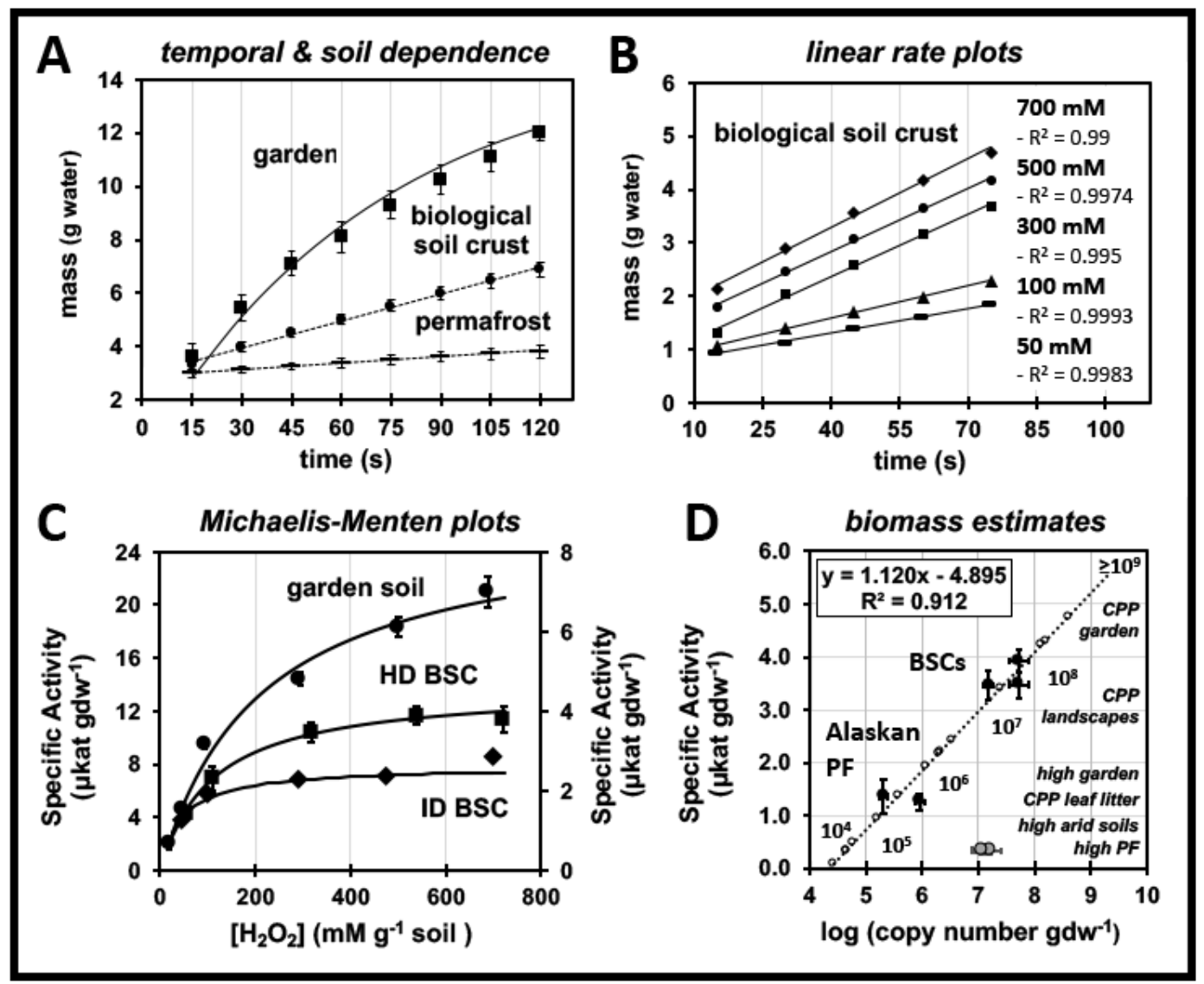

981

982

983

984

985

986

987

988

989

990

991

992

993

994

995

996

997

998

Figure 1. Kinetics and Michaelis-Menten analyses of soil catalase activities using volume displacement: (A)

Temporal change in the mass of displaced water using highly irrigated garden soils (CPP.BioTrek.Garden), topsoils of biological soil crusts (BSCs obtained from areas of high surface density (Mojave.BSC.HD.Top), and $33 \mathrm{ky}$ permafrost (Alaska.PF.33ky; 35k8C); errors bars represent the standard deviation $(n=3)$ and, for display purposes, trendlines for garden soils were estimated using psuedo-first order kinetics $\left([B]=[A]_{0}\left(1-e^{-k t}\right)\right.$; where $[A]_{0}$ and $k$ were artificially set at $15 \mathrm{~g}$ and $\left.0.014 \mathrm{~s}^{-1}\right)$. (B) Impact of substrate concentration (50-700 mM) on the catalase activities for BSC topsoils, where linear regression of the rate plots from 15-75s provided $R^{2} \geq 0.99$. (C) Michaelis-Menten analyses for garden soils (left y-axis), and biological soil crusts (right y-axis) sampled from sites of high (HD) and intermediate (ID) surface densities; specific activities were expressed as $\mu$ kat per gram dry weight $\left(\mu k^{2} ~ g d w^{-1}\right)$, errors bars represent the standard deviation $(n=3)$, and fits to the data were obtained using Equation 8. (D) Standard curve (black squares; $R^{2}=0.91$ ) representing relationship between catalase specific activities ( $\mu$ kat per gram dry weight; $\mu k$ at $_{\text {gdw }}{ }^{-1}$ ) and rRNA gene copy numbers (log copy number) using HD- and ID-BSCs (Mojave.BSC.HD.Top.CPP, Mojave.BSC.HD.Top.DSC, and Mojave.BSC.ID.Top.DSC), and 19 and 33 ky Alaskan permafrost (Alaska.PF.33ky and Alaska.PF.19ky); error bars along both axes represent the standard error $(n=3)$, BSC subsurfaces are shown for comparison (gray circles), the $10^{x}$ labels represent probable biomass increments, and estimates of biomass (open circles) for Cal Poly Pomona (CPP) and Ladakh soils are listed (italics) in respective order. 
Figure 2.

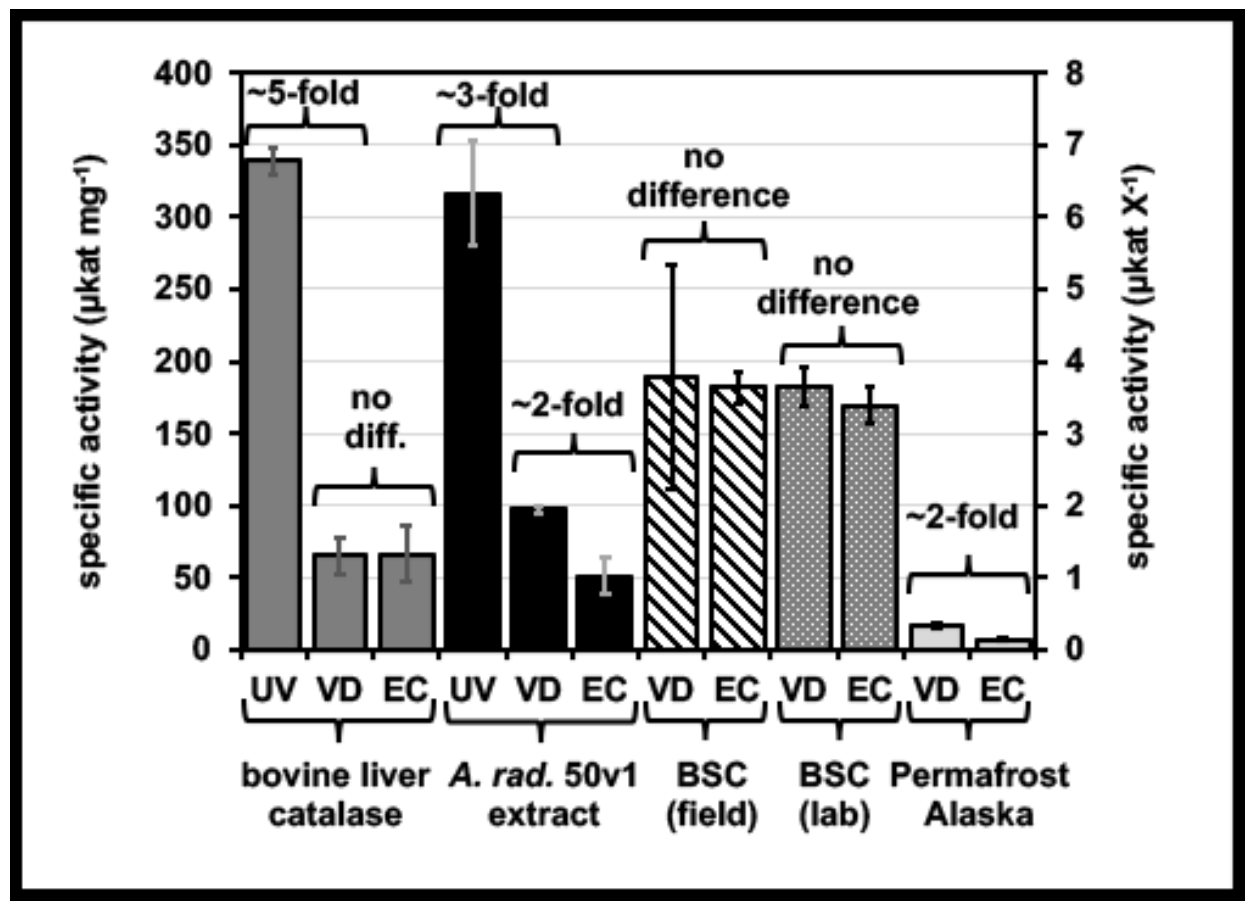

Figure 2. Comparison of catalase specific activities as measured by volume displacement (VD), electrochemical

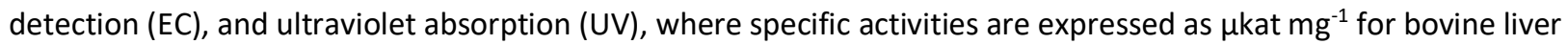

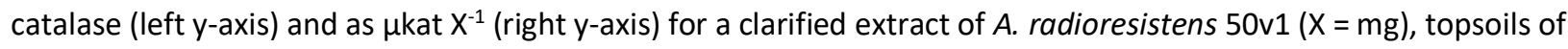
biological soil crusts (BSCs) $(X=g)$, and permafrost $(X=g)$; error bars represent the standard deviation $(n \geq 3)$, and all assays were conducted in $50 \mathrm{mM}$ HEPES ( $\mathrm{pH} 7.5$ ) using non-stabilized hydrogen peroxide, except for the BSC field assays which used stabilized hydrogen peroxide, and permafrost assays which used PBS. 


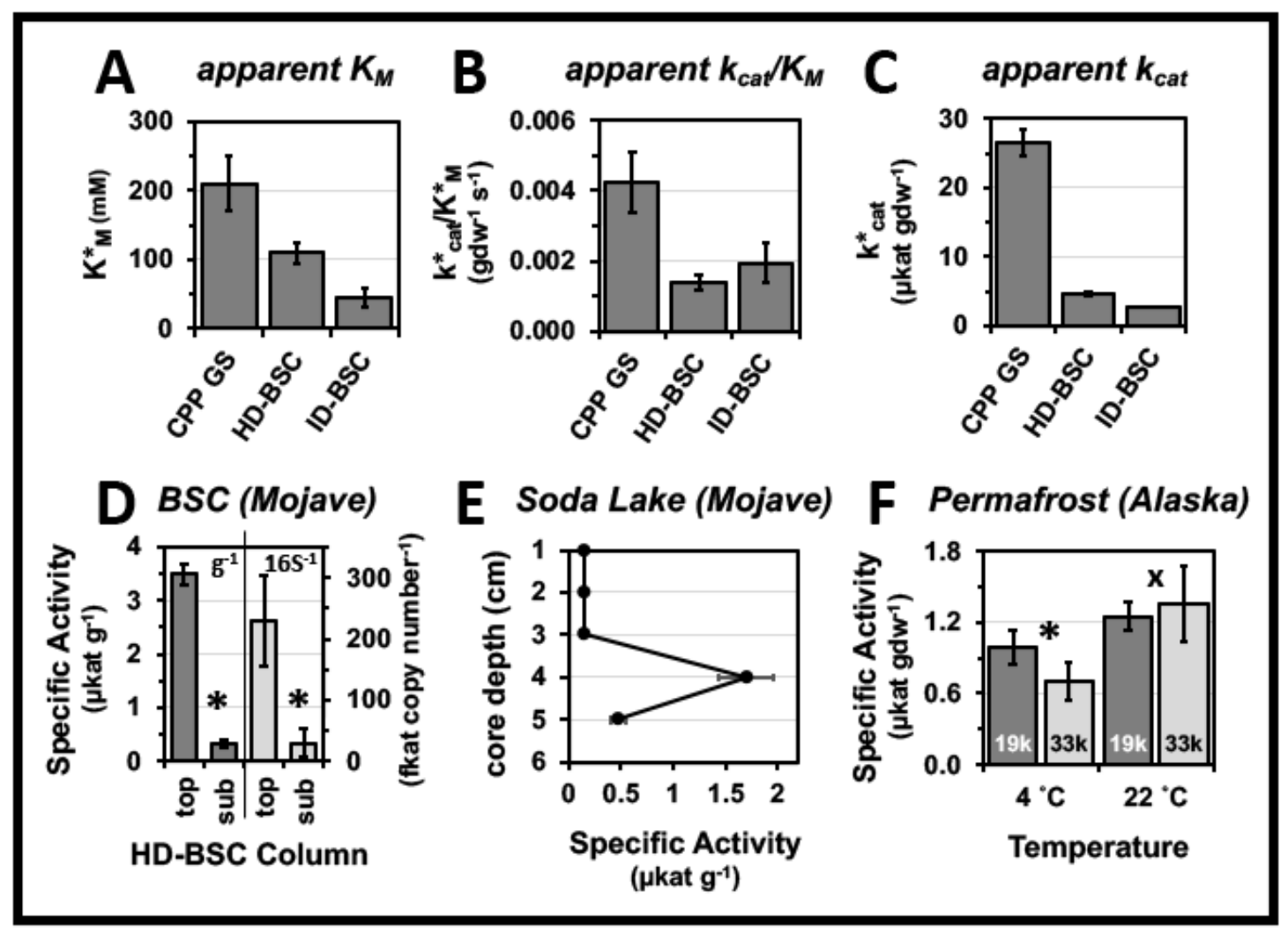

Figure 3. Trends across soil catalase kinetics and specific activities where statistical comparisons are marked $\left({ }^{*} p\right.$ $<0.05$; ${ }^{\mathrm{p}}>0.05$ ): Comparison of the Michaelis-Menten kinetic parameters for (A) $K_{M}^{*}$, (B) $k_{c a t}^{*} / K_{M}^{*}$, (C) and $k_{c a t}^{*}$ across highly irrigated garden soils (CPP GS; CPP.BioTrek.Garden), and topsoils of biological soil crusts (BSCs) sampled from sites of high (HD-BSC; BSC.HD.Mojave.Lab) and intermediate (ID-BSC; BSC.ID.Mojave.Lab) surface densities; rates for CPP GS and HD-BSC were measured in triplicate ( $n=1$ for ID-BSC), and error bars represent the standard error of the regression. (D) Comparison of specific activities for HD-BSCs along the vertical column structure (topsoil vs. subsurface = top vs. sub) where specific activities are expressed as $\mu$ kat per total soil mass (left y-axis; $\mu$ kat g $^{-1}$ ) and fkat per $16 \mathrm{~S}$ rRNA gene copy number (right y-axis; fkat copy number ${ }^{-1}$ ); error bars represent the propagated error $(n=3)$. (E) Change in specific activities $\left(\mu k a \mathrm{~g}^{-1}\right)$ along a depth profile for a compressed dry lake bed core; error bars represent the standard deviation $(n=2)$. (F) Comparison of specific activities of 19 ky and 33 ky permafrost (Alaska.PF.33ky \& Alaska.PF.19ky) measured at 4 and $22^{\circ} \mathrm{C}$, and expressed 
Figure 4.

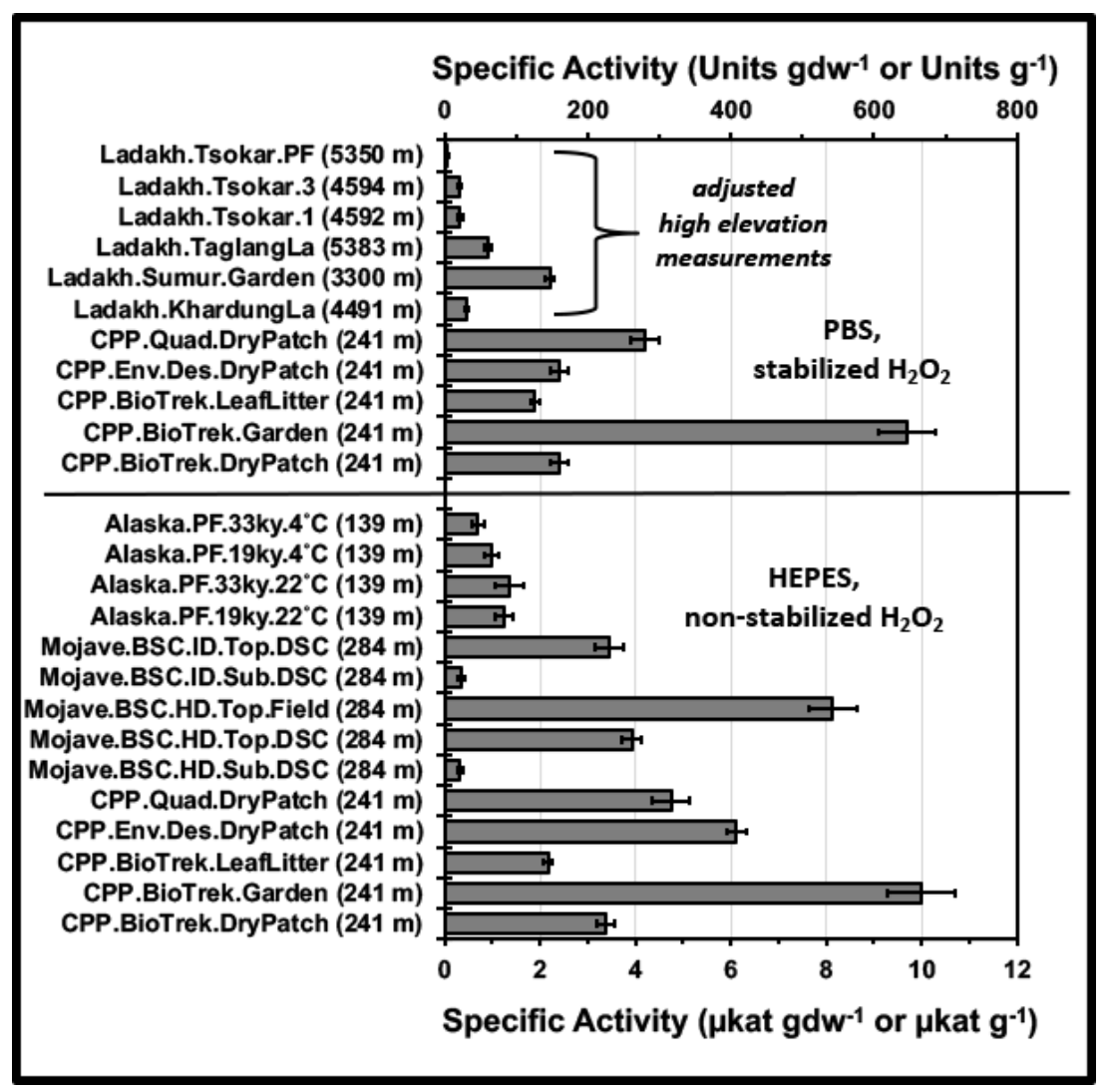

Figure 4. Comparison of barometrically adjusted catalase specific activities across differing soils (Table S1)

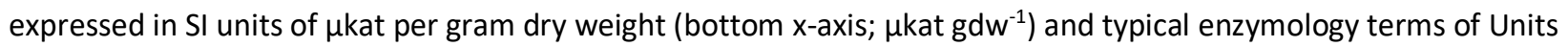
per gram dry weight (top $\mathrm{x}$-axis; Units $\mathrm{gdw}^{-1}$ ), with all Ladakh samples being expressed per total soil mass $\left(\mathrm{g}^{-1}\right)$; measurements listed in the top panel were obtained in $1 \times$ PBS and $330 \mathrm{mM}(1 \% \mathrm{w} / \mathrm{w})$ stabilized hydrogen peroxide, measurements listed in the bottom panel were obtained in $50 \mathrm{mM}$ HEPES (pH 7.5) and $330 \mathrm{mM} \mathrm{(1 \%}$ $w / w)$ non-stabilized hydrogen peroxide, all error bars represent the standard deviation $(n \geq 3)$, sampling site elevations are given in parentheses, and elevations for measurements were $241 \mathrm{~m}$ (CPP.X soils, Mojave.HD.BSC.Top.CPP, \& Alaska.PF.X), 284 m (Mojave.BSC.HD.Top.Field, Mojave.BSC.HD/ID.Top.DSC, \& 
Figure 5.

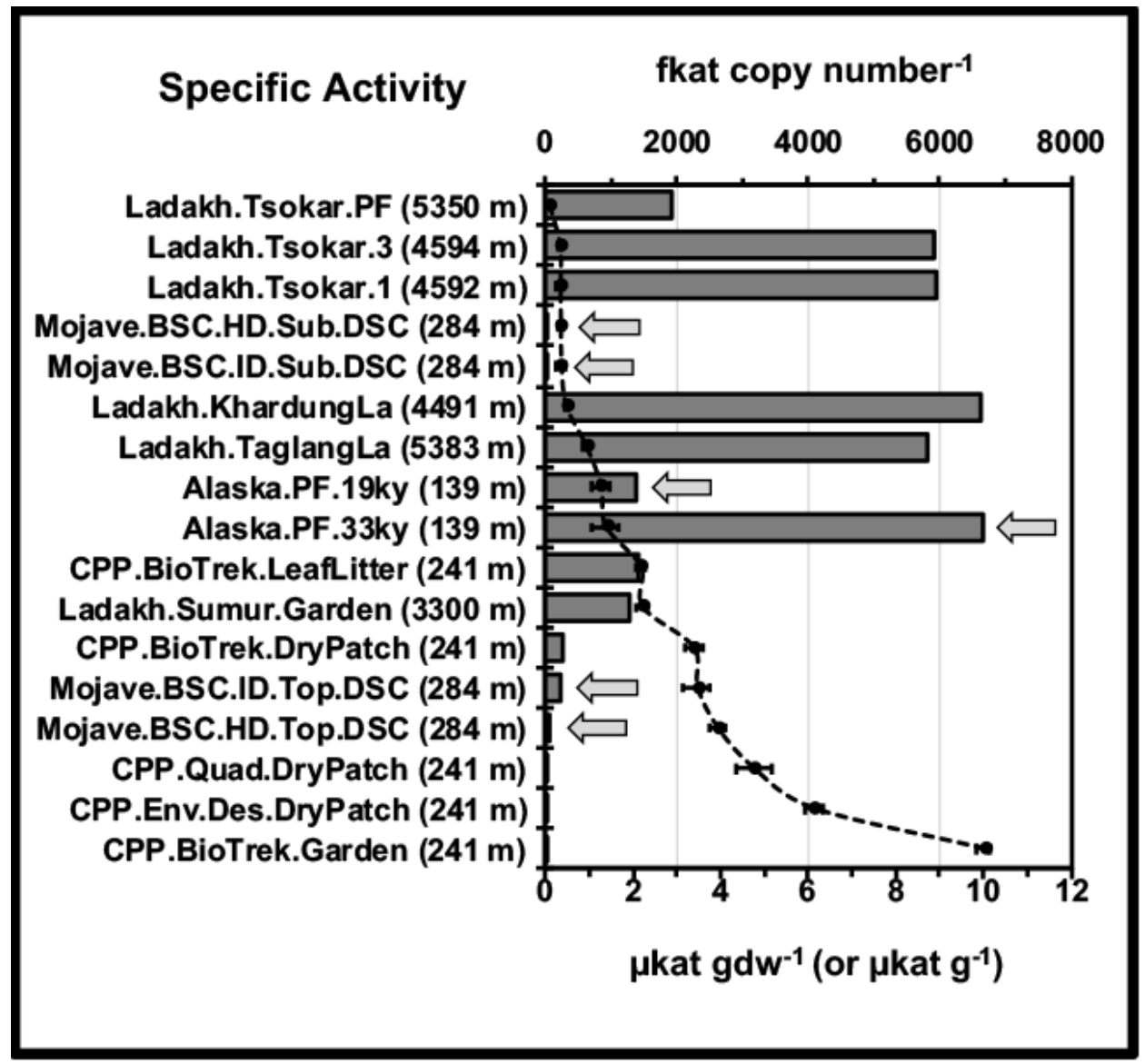

Figure 5. Comparison of specific activity (SA) values expressed per biomass (top $x$-axis; bars) and soil mass (bottom x-axis; black circles), where SAs per biomass are expressed in units of fkat per $16 \mathrm{~S}$ rRNA gene copy number (fkat copy number ${ }^{-1}$ ) and SAs per soil mass are expressed in units of $\mu$ kat per gram dry weight $\left(\mu k a t\right.$ gdw $^{-1}$ ), or per total total mass for the Ladakh samples $\left(\mu \mathrm{kat} \mathrm{g}^{-1}\right)$; samples (y-axis) are listed in order of increasing SA per soil mass (top to bottom), arrows denote measured 16S rRNA copy number values (with all others being calculated), dotted line represents the trend, and error bars represent the standard deviation for the specific activities per soil mass along the $\mathrm{x}$-axis $\left(\mu \mathrm{kat} \mathrm{gdw}^{-1}\right.$, or $^{-1} ; \mathrm{n} \geq 3$ ). 


\section{Supplementary Material}

1051

1052

1053

1054

1055

1056

1057

1058

1059

1060

1061

1062

1063

1064

1065

1066

1067

1068

1069

1070

1071

1072

1073

1074

1075

1076

1077

1078

1079

1080

1081

1082

1083

1084

1085

1086

\section{Assembly of Volume Displacement Apparatus}

The volume displacement (VD) apparatus was assembled using common laboratory supplies (Diagram 1 \& Figures S1A-C); no major purchases were required for reliable and longterm operation of the apparatus. Materials included two $50 \mathrm{~mL}$ conical tubes, a tube rack, $<3 \mathrm{ft}$ of Tygon tubing (1/8 in, 1/4 in, 1/16 in), 1 one-hole rubber stopper (1.4 x 1.1 in), 1 two-hole rubber stopper (1.4 x $1.1 \mathrm{in}$ ), parafilm (optional), a $15 \mathrm{~mL}$ graduated cylinder (or a 15 or $50 \mathrm{~mL}$ conical tube), a mass balance (minimum accuracy of $0.01 \mathrm{~g}$ ), a stir plate, $3 \mathrm{~mm}$ magnetic stir bar, and a stopwatch. Solid rubber stoppers were drilled (size $1 \mathrm{drill}$ bit) to produce one or two holes (as shown Figure S1A).

As illustrated in Diagram 1, apparatus assembly entailed sequential connection of three chambers, which were respectively used for mixing (conical tube), water displacement (conical tube) and water collection (graduated cylinder or conical tube). The chambers were connected using a minimum amount of Tygon tubing (Tubes A \& B), which were threaded through the rubber stoppers using needle-nose pliers. The one-hole rubber stopper was used to seal the mixing chamber ( $1^{\text {st }}$ chamber), and the two-hole rubber stopper was used to seal the displacement chamber $\left(2^{\text {nd }}\right.$ chamber). To connect the mixing and displacement chambers, Tube A ( $\sim 5-6 \mathrm{in}, \sim 12-15 \mathrm{~cm}$ ) was threaded through the one- and two-hole rubber stoppers, and trimmed $<2 \mathrm{~cm}$ from the bottom edge of each stopper. To

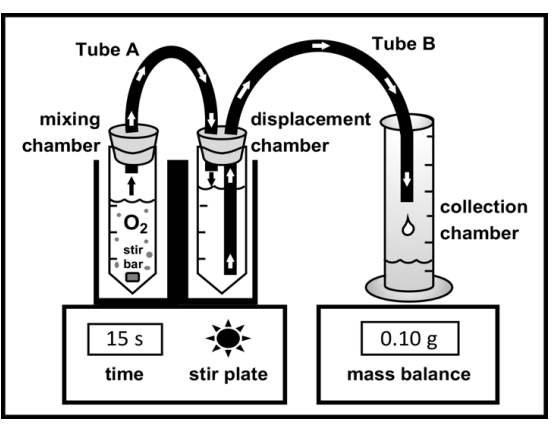

Diagram 3. Volume displacement device with sequentially connected mixing, displacement, and collection chambers. connect the displacement and collection chambers, Tube B ( $14-15$ in, $~ 35-38 \mathrm{~cm}$ ) was threaded through the two-hole rubber stopper, trimmed $\sim 1 \mathrm{~cm}$ from the from the base of the mixing chamber, and inserted into the collection chamber.

For the enzyme assay, the mixing and displacement chambers were inserted into a mini tube rack (as shown in Figure S1B) and placed on a stir plate, while the collection chamber was placed on a mass balance. Upon addition of substrate to the mixed soil suspension, the mixing chamber was immediately sealed with the one-hole rubber stopper. In turn, soil enzyme activity was monitored by following the change in mass of the collection chamber over time (alternatively, in early control experiments, changes in volume were measured using a graduated cylinder). Occasionally, the mixing chamber was wrapped in parafilm; however, no observable changes in the rates of mass or volume displacement were noted. In control experiments, priming of the connective tubing with water (with clamped control of flow into 
the collection chamber) yielded an $\leq 10 \%$ increase in rates; however, the time required per experiment commensurately increased 3-4-fold.

\section{Assembly of Electrochemical Apparatus}

For the electrochemical analyses, a $\mathrm{O}_{2}$ Gas Sensor (O2-BTA) and LabQuest 2 (LABQ2) data logger were purchased from Vernier Software \& Technology with respective list costs of \$199 and \$329. Along with these connected components, the electrochemical apparatus was assembled using a support stand ( $15-24$ in tall), 3-prong clamp, magnetic stir plate, $3 \mathrm{~mm}$ stir bar, $50 \mathrm{~mL}$ conical tube (mixing chamber), one and two-hole rubber stoppers, Tygon tubing, two plastic stopcocks, and parafilm.

For lower activity samples (e.g., permafrost), the sensor was directly fitted into the mixing chamber ( $50 \mathrm{~mL}$ conical tube) and sealed with parafilm (Figure S1D). For higher activity samples (e.g., BSCs and garden soils), the mixing chamber was connected to the sensor using Tygon tubing, stopcocks, and rubber stoppers. For this configuration, Tygon tubes of differing length (Tubes A-C) were prepared (Tube A: 6-7 in, 15-18 cm; Tube B: $\sim 4-5$ in, $~ 10-13 \mathrm{~cm}$; Tube C: 3-4 in; 8-10 cm), where Tubes A and B were threaded through a two-hole rubber stopper, Tube $C$ was threaded through a one-hole rubber stopper, and all tubes were trimmed $\sim 1-3 \mathrm{~cm}$ from the bottom edge of the stoppers. Plastic stopcocks were attached to end of Tubes $A$ and $B$ (leading from the top of the stopper); while Tube $C$ was fastened onto the opposite end of the stopcock attached to Tube A. The two-hole rubber stopper (threaded with Tubes $A$ and $B$ ) was used to seal the mixing chamber. The one-hole rubber stopper (threaded with Tube C) was used to seal the electrochemical sensor. In this configuration, Tube A served as an exit line (for the mixing chamber) and connected to Tube $C$ via a stopcock, Tube $C$ connected the sensor, and tube B served as an escape line for the mixing chamber.

When conducting the kinetic assay, the sensor was secured to a support stand using a 3prong clamp, the mixing chamber was inserted into a mini tube rack, and mixing of the suspension was accomplished using a magnetic stir plate and $3 \mathrm{~mm}$ stir bar. In between assay runs, the apparatus and sensor were re-equilibrated to atmospheric conditions by removing the mixing chamber from the sensor (i.e., breaking the parafilm seal), or by opening the escape valve (i.e., opening the stopcock on Tube B). 
bioRxiv preprint doi: https://doi.org/10.1101/2020.06.11.147595; this version posted June 12, 2020. The copyright holder for this preprint (which was not certified by peer review) is the author/funder. All rights reserved. No reuse allowed without permission.

Supplementary Table 1. List and description of sampled soils.

1124

\begin{tabular}{|c|c|c|c|c|c|c|c|c|c|c|c|c|c|c|c|c|}
\hline 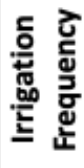 & 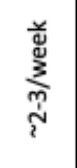 & 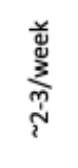 & 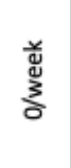 & 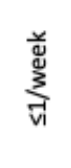 & 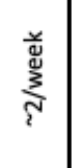 & $\begin{array}{l}\text { 管 } \\
\text { 总 }\end{array}$ & อี & $\stackrel{\pi}{\mathrm{E}}$ & $\stackrel{\pi}{\varepsilon}$ & กั & อ & กั & $\stackrel{\pi}{\mathrm{I}}$ & $\stackrel{\pi}{\Sigma}$ & อี & $\stackrel{\pi}{E}$ \\
\hline 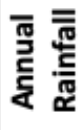 & $\begin{array}{l}\text { E } \\
\text { E } \\
\text { 号 }\end{array}$ & $\begin{array}{l}E \\
E \\
\text { 品 }\end{array}$ & 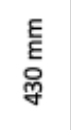 & $\begin{array}{l}E \\
E \\
\stackrel{y}{g}\end{array}$ & $\begin{array}{l}E \\
\text { E } \\
\text { O } \\
\text { g }\end{array}$ & $\begin{array}{l}E \\
\underline{E} \\
\stackrel{్}{ }\end{array}$ & $\begin{array}{l}E \\
E \\
\stackrel{E}{\circ}\end{array}$ & $\begin{array}{l}E \\
E \\
\stackrel{一}{E}\end{array}$ & 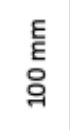 & 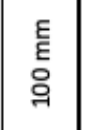 & $\begin{array}{l}\text { E } \\
\text { Бू }\end{array}$ & $\begin{array}{l}\text { E } \\
\text { \&ू }\end{array}$ & 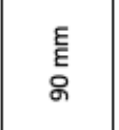 & 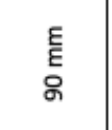 & $\begin{array}{l}\text { E } \\
\text { Бू }\end{array}$ & $\begin{array}{l}E \\
E \\
\stackrel{E}{2} \\
\stackrel{2}{N}\end{array}$ \\
\hline 흘 & $\vec{山}$ & ज्ञ & 岃 & 岕 & 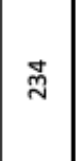 & ষ্ল & 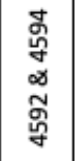 & 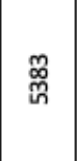 & 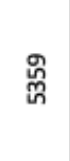 & 品 & 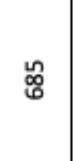 & 岕 & 号 & 乌ั & $\stackrel{\mathscr{\sim}}{\sim}$ & g్ \\
\hline 气ั & 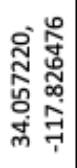 & 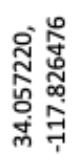 & 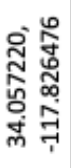 & 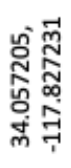 & 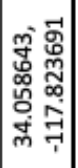 & 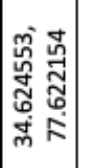 & 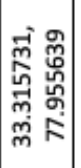 & 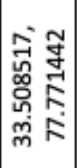 & 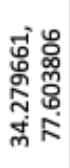 & 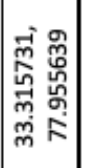 & 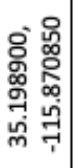 & 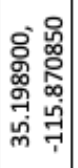 & 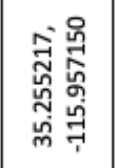 & 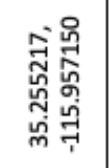 & 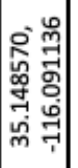 & 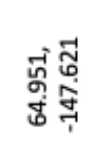 \\
\hline 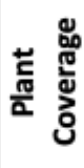 & 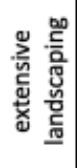 & 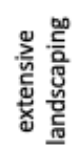 & 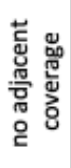 & 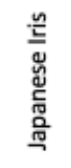 & 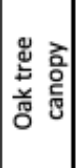 & 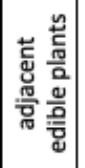 & 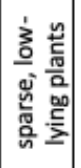 & 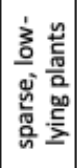 & 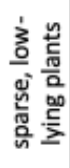 & $\stackrel{\pi}{2}$ & 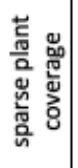 & 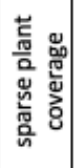 & 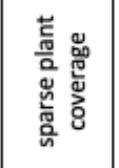 & 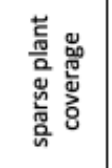 & อ & อี \\
\hline 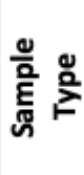 & 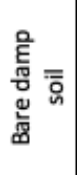 & 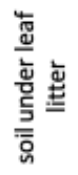 & 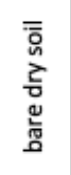 & 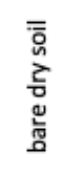 & 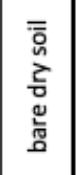 & 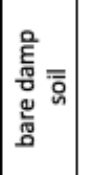 & 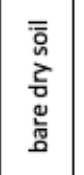 & 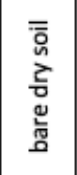 & 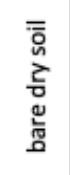 & 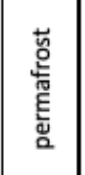 & 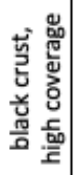 & 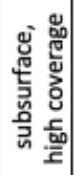 & 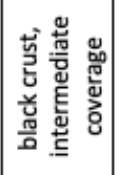 & 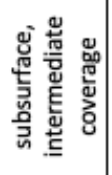 & 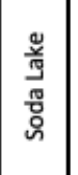 & 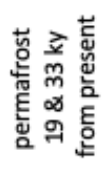 \\
\hline 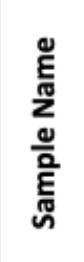 & 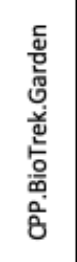 & 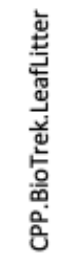 & 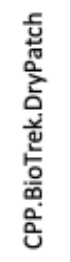 & 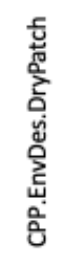 & 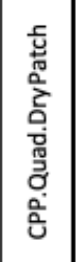 & 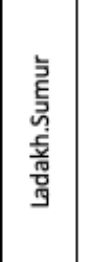 & 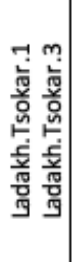 & 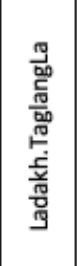 & 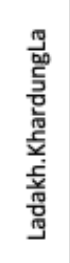 & 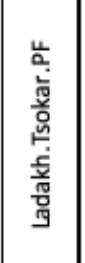 & 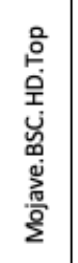 & 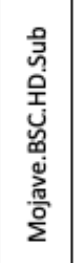 & 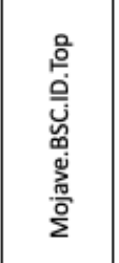 & 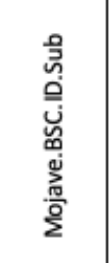 & 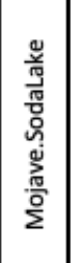 & 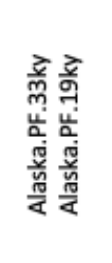 \\
\hline 들 & & & 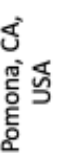 & & & 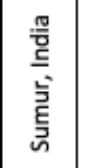 & 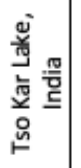 & 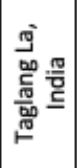 & 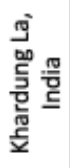 & 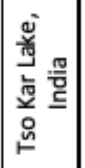 & & & 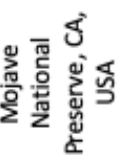 & & & 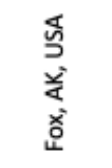 \\
\hline 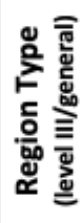 & & & 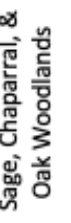 & & & 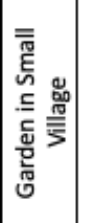 & 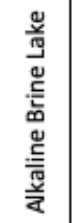 & 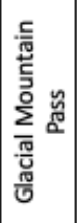 & 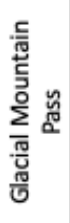 & 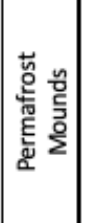 & & & 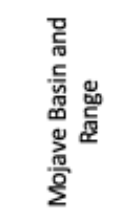 & & & 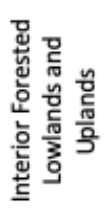 \\
\hline $\begin{array}{l}\text { 흠 } \\
\text { 현 }\end{array}$ & & 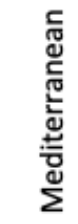 & 窇 & & & & & 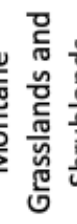 & & & & & 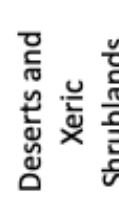 & & & 兽 \\
\hline
\end{tabular}


Supplementary Table 2. List of catalase specific activities (SAs) expressed per gram dry weight ( $\mu$ kat $\mathrm{gd}^{-1}$ ) and $16 \mathrm{~S}$ rRNA copy number (fkat copy number ${ }^{-1}$; abbreviated as fkat $16 \mathrm{~S}^{-1}$ ); where

1127 standard deviations for SAs per gdw are provided, SAs for Ladakh are expressed per gram,

1128 calculated estimates of 165 rRNA copy numbers are from a standard curve, and measured copy

1129 numbers are from Mogul et al. 2017 and Mackelprang et al 2017.

\begin{tabular}{|c|c|c|c|c|c|c|}
\hline Sample & $\begin{array}{c}\mu k a t \text { gdw } \\
\left(\text { or g }^{-1}\right)\end{array}$ & stdev & $\begin{array}{l}\text { Units gdw } \mathbf{w}^{-1} \\
\left(\text { or }^{-1}\right)\end{array}$ & $\begin{array}{l}\text { calc } \\
16 S^{a}\end{array}$ & $\begin{array}{c}\text { measured } \\
16 S^{a}\end{array}$ & $\left(\text { fkat } 16 S^{-1}\right)^{a}$ \\
\hline \multicolumn{7}{|c|}{$50 \mathrm{mM}$ HEPES (pH 7.5), $330 \mathrm{mM}$ non-stabilized $\mathrm{H}_{2} \mathrm{O}_{2}(1 \% \mathrm{w} / \mathrm{w})$} \\
\hline CPP.BioTrek.DryPatch (241 m) & $3.4 \mathrm{E}+00$ & 2.0E-01 & $2.0 \mathrm{E}+02$ & $1.4 \mathrm{E}+07$ & & $2.5 \mathrm{E}+02$ \\
\hline CPP.BioTrek.Garden (241 m) & $1.0 \mathrm{E}+01$ & 7.0E-01 & $6.0 \mathrm{E}+02$ & $2.3 \mathrm{E}+12$ & & 4.4E-03 \\
\hline CPP.BioTrek.LeafLitter (241 m) & $2.2 \mathrm{E}+00$ & $1.0 \mathrm{E}-01$ & $1.3 \mathrm{E}+02$ & $1.5 \mathrm{E}+06$ & & $1.4 \mathrm{E}+03$ \\
\hline CPP.Env.Des.DryPatch (241 m) & $6.1 \mathrm{E}+00$ & 2.0E-01 & $3.7 \mathrm{E}+02$ & $2.0 \mathrm{E}+09$ & & $3.1 \mathrm{E}+00$ \\
\hline CPP.Quad.DryPatch (241 m) & $4.7 \mathrm{E}+00$ & 4.0E-01 & $2.8 \mathrm{E}+02$ & $1.6 \mathrm{E}+08$ & & $2.9 \mathrm{E}+01$ \\
\hline Mojave.BSC.HD.Sub.DSC (284 m) & $3.3 E-01$ & $5.0 E-02$ & $2.0 \mathrm{E}+01$ & & $1.5 \mathrm{E}+07$ & $2.2 \mathrm{E}+01$ \\
\hline Mojave.BSC.HD.Top.DSC (284 m) & $3.9 E+00$ & 2.0E-01 & $2.4 \mathrm{E}+02$ & & $5.3 \mathrm{E}+07$ & $7.4 \mathrm{E}+01$ \\
\hline Mojave.BSC.HD.Top.Field (284 m) & $8.1 \mathrm{E}+00$ & 5.0E-01 & $4.9 \mathrm{E}+02$ & & $5.3 \mathrm{E}+07$ & $1.5 \mathrm{E}+02$ \\
\hline Mojave.BSC.ID.Sub.DSC (284 m) & $3.4 E-01$ & $8.0 E-02$ & $2.1 \mathrm{E}+01$ & & $1.1 \mathrm{E}+07$ & $3.0 \mathrm{E}+01$ \\
\hline Mojave.BSC.ID.Top.DSC (284 m) & $3.5 \mathrm{E}+00$ & 3.0E-01 & $2.1 \mathrm{E}+02$ & & $1.5 \mathrm{E}+07$ & $2.3 \mathrm{E}+02$ \\
\hline Alaska.PF.19ky.22 ${ }^{\circ} \mathrm{C}(139 \mathrm{~m})$ & $1.3 \mathrm{E}+00$ & 2.0E-01 & $7.5 \mathrm{E}+01$ & & $9.0 \mathrm{E}+05$ & $1.4 \mathrm{E}+03$ \\
\hline Alaska.PF.33ky. $22^{\circ} \mathrm{C}(139 \mathrm{~m})$ & $1.4 \mathrm{E}+00$ & 3.0E-01 & $8.2 E+01$ & & $2.0 \mathrm{E}+05$ & $6.7 \mathrm{E}+03$ \\
\hline Alaska.PF.19ky. $4^{\circ} \mathrm{C}(139 \mathrm{~m})$ & 9.9E-01 & $1.5 \mathrm{E}-01$ & $5.9 \mathrm{E}+01$ & & $9.0 \mathrm{E}+05$ & $1.1 \mathrm{E}+03$ \\
\hline Alaska.PF.33ky. $4^{\circ} \mathrm{C}(139 \mathrm{~m})$ & 7.0E-01 & $1.2 \mathrm{E}-01$ & $4.2 \mathrm{E}+01$ & & $2.0 \mathrm{E}+05$ & $3.4 \mathrm{E}+03$ \\
\hline \multicolumn{7}{|c|}{ 1x PBS, stabilized $330 \mathrm{mM} \mathrm{H}_{2} \mathrm{O}_{2}(1 \% \mathrm{w} / \mathrm{w})$} \\
\hline CPP.BioTrek.DryPatch (241 m) & $2.4 \mathrm{E}+00$ & 2.0E-01 & $1.4 \mathrm{E}+02$ & $2.4 \mathrm{E}+06$ & & $1.0 \mathrm{E}+03$ \\
\hline CPP.BioTrek.Garden (241 m) & $9.7 \mathrm{E}+00$ & $6.0 \mathrm{E}-01$ & $5.8 \mathrm{E}+02$ & $1.4 \mathrm{E}+12$ & & 7.1E-03 \\
\hline CPP.BioTrek.LeafLitter (241 m) & $1.9 \mathrm{E}+00$ & $1.0 \mathrm{E}-01$ & $1.1 \mathrm{E}+02$ & $9.5 \mathrm{E}+05$ & & $2.0 \mathrm{E}+03$ \\
\hline CPP.Env.Des.DryPatch (241 m) & $2.4 \mathrm{E}+00$ & $2.0 \mathrm{E}-01$ & $1.4 \mathrm{E}+02$ & $6.2 \mathrm{E}+07$ & & $3.9 \mathrm{E}+01$ \\
\hline CPP.Quad.DryPatch (241 m) & $4.2 \mathrm{E}+00$ & 3.0E-01 & $2.5 \mathrm{E}+02$ & $7.0 \mathrm{E}+07$ & & $6.0 \mathrm{E}+01$ \\
\hline Ladakh.KhardungLa (4491 m) $\left(\mathbf{g}^{-1}\right)$ & $4.5 E-01$ & $3.0 E-02$ & $2.7 \mathrm{E}+01$ & $6.8 \mathrm{E}+04$ & & $6.6 \mathrm{E}+03$ \\
\hline Ladakh.Sumur $(3300 \mathrm{~m})\left(\mathbf{g}^{-1}\right)$ & $2.2 E+00$ & $1.1 E-01$ & $1.3 \mathrm{E}+02$ & $2.1 \mathrm{E}+06$ & & $1.1 \mathrm{E}+03$ \\
\hline 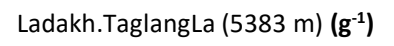 & $9.1 E-01$ & $6.0 E-02$ & $5.5 \mathrm{E}+01$ & $1.6 \mathrm{E}+05$ & & $5.8 \mathrm{E}+03$ \\
\hline Ladakh.Tsokar.1 (4592 m) $\left(\mathbf{g}^{-1}\right)$ & $3.2 E-01$ & $6.0 E-02$ & $1.9 \mathrm{E}+01$ & $5.3 \mathrm{E}+04$ & & $6.0 \mathrm{E}+03$ \\
\hline Ladakh.Tsokar.3 (4594 m) $\left(\mathbf{g}^{-1}\right)$ & $3.1 E-01$ & 4.0E-02 & $1.9 \mathrm{E}+01$ & $5.3 \mathrm{E}+04$ & & $5.9 \mathrm{E}+03$ \\
\hline 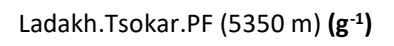 & $6.5 E-02$ & $3.0 E-02$ & $3.9 \mathrm{E}+00$ & $3.4 \mathrm{E}+04$ & & $1.9 \mathrm{E}+03$ \\
\hline
\end{tabular}


bioRxiv preprint doi: https://doi.org/10.1101/2020.06.11.147595; this version posted June 12, 2020. The copyright holder for this preprint (which was not certified by peer review) is the author/funder. All rights reserved. No reuse allowed without permission.

Supplementary Figure 1. Differing configurations and components of the catalase assay devices displaying (A) one- and two-hole stoppers with threaded tubing, (B) sequential connections of the mixing, displacement, and collection chambers in the VD device (left to right), (C) battery-operated mixer and scale for VD, (D) EC device with a direct connection between the mixing chamber and sensor, and (E) example field analysis.

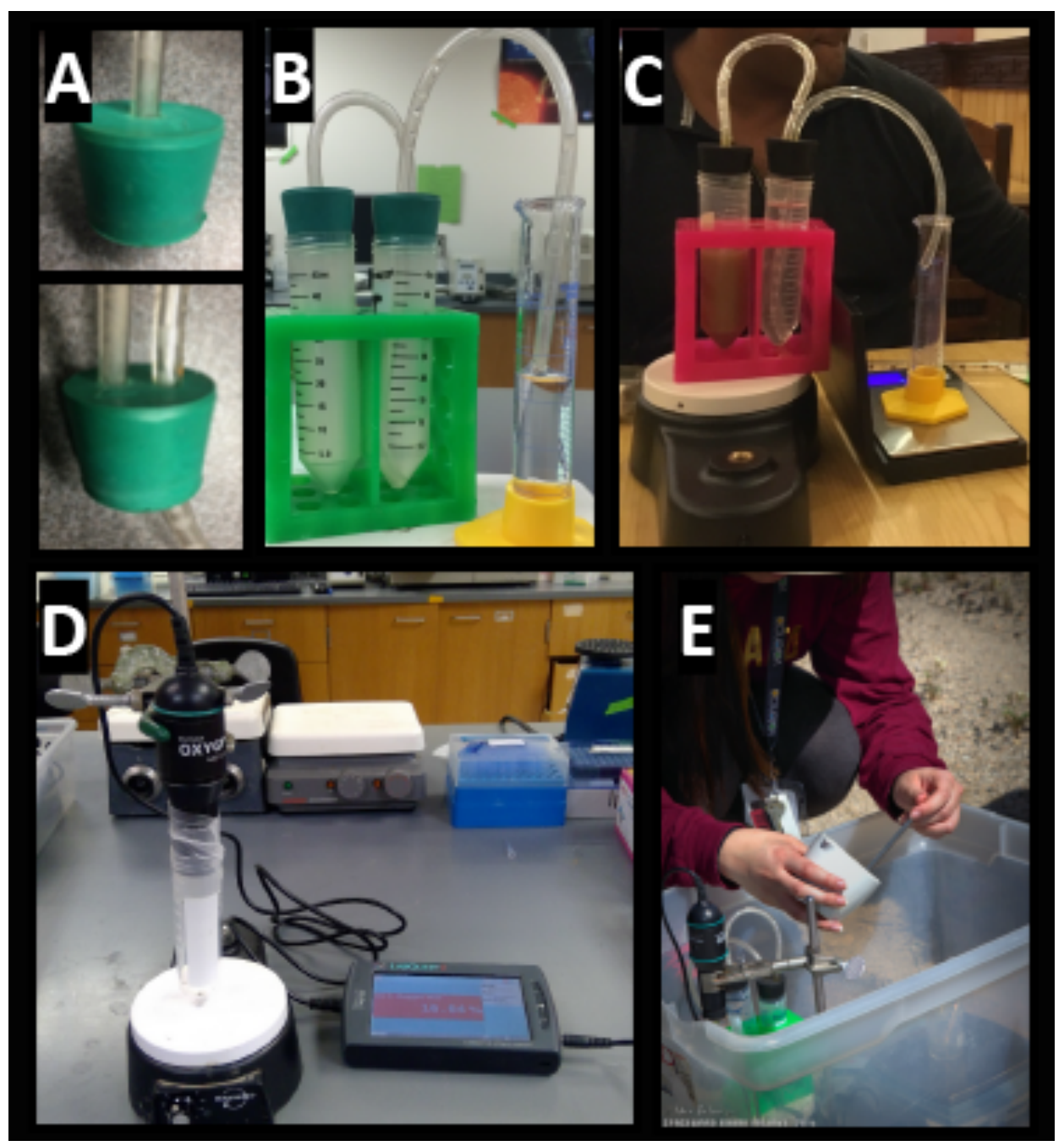


Supplementary Figure 2. Impacts of (A) buffer type (HEPES vs. PBS) and (B) substrate formulation (stabilized vs. non-stabilized hydrogen peroxide) on the catalase specific activities, where soil samples are arranged (left to right) from highly irrigated (CPP.BioTrek.Garden) to infrequently irrigated (CPP.Env.Design.DryPatch) or arid soils (Mojave.BSC.Field), and low activity Alaskan permafrost (35k9B) is included in the inset plot; specific activities

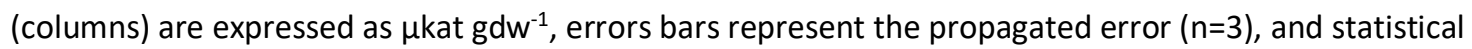
comparisons are marked $\left(* p<0.05 ; x_{p}>0.05\right)$.

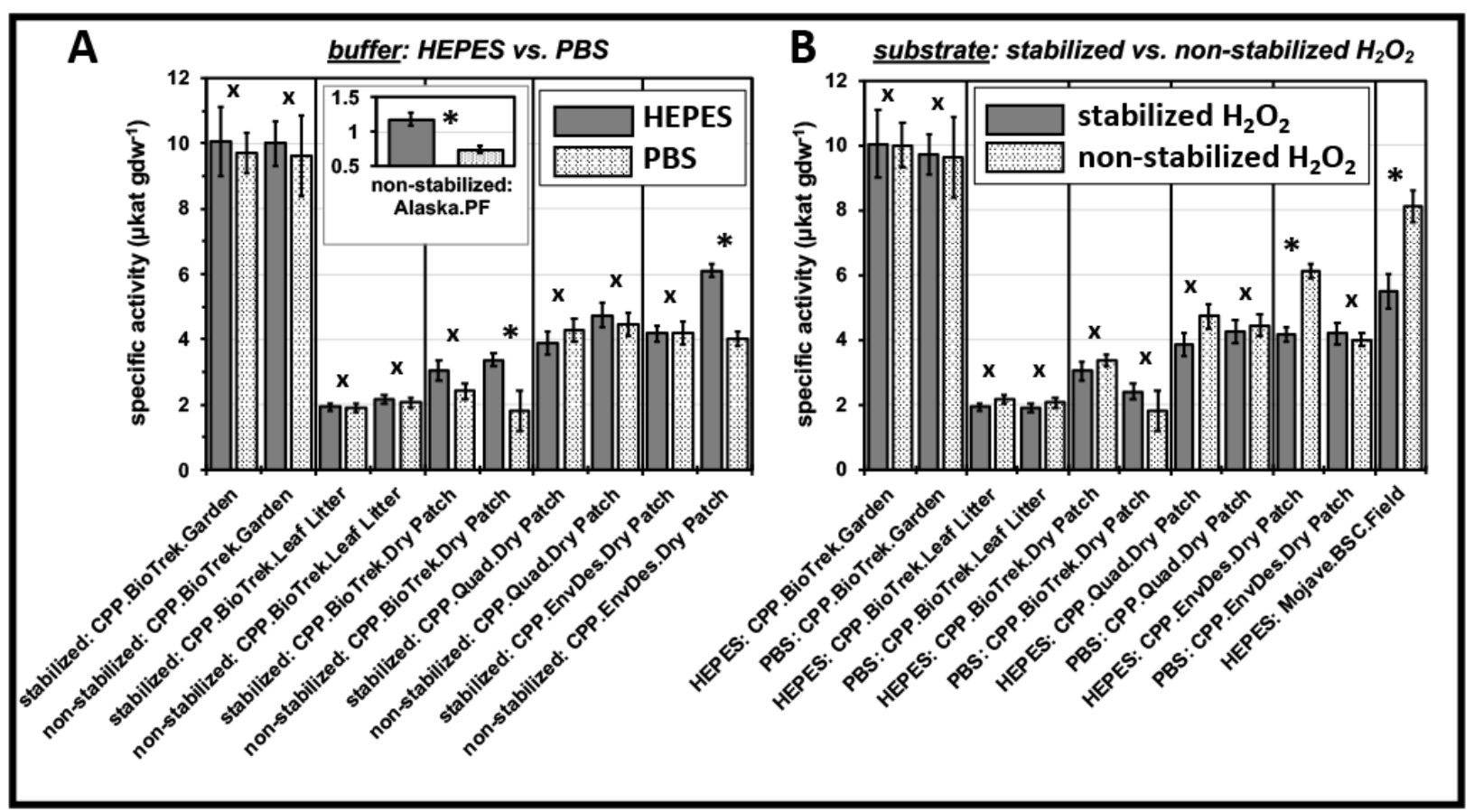

